\title{
Critical capabilities for effective management of complementarity between product and process innovation: Cases from the food and drink industry
}

\author{
Hullova Dusana ${ }^{a}$, Simms Christopher Don ${ }^{\mathrm{b}}$, Trott Paul ${ }^{\mathrm{c}}$, Laczko Pavel ${ }^{\mathrm{d}}$ \\ ${ }^{a}$ University of Portsmouth, Portsmouth Business School, Richmond Building, Portland Street, Portsmouth PO1 \\ 3DE,UK.dusana.hullova@port.ac.uk,tel.00447459108201 (corresponding author) \\ ${ }^{b}$ University of Portsmouth, Portsmouth Business School, Richmond Building, Portland Street, Portsmouth PO1 \\ 3DE,UK.chris.simms@port.ac.uk \\ ${ }^{c}$ University of Portsmouth, Portsmouth Business School, Richmond Building, Portland Street, Portsmouth PO1 \\ 3DE,UK. paul.trott@port.ac.uk \\ ${ }^{d}$ University of Portsmouth, Portsmouth Business School, Richmond Building, Portland Street, Portsmouth, \\ PO13DE,UK. pavel.laczko@port.ac.uk
}

\begin{abstract}
The management of the complementarity between product and process innovation has been discussed for five decades. The most recent advancement in the conceptual development uncovered different extents of complementarities occurring between product and process innovation at the project level. Prior literature suggested that facilitating a better interplay between these two types of innovation holds the potential for the development of a longlasting competitive advantage. Despite its theoretical and managerial importance, management of new product and process development (NPPD) projects with different extents of complementarity between product and process innovation remains poorly understood. To address this gap, we adopt perspectives from contingency theory and dynamic capabilities. Building upon Hullova, Trott and Simms's (2016) classification of complementarities we investigate the management of different complementarity types in four NPPD projects in the UK food and drink industry. We introduce empirically derived framework for identification, management and leveraging of the complementarity between product and process innovation. The framework identifies three critical capabilities and associated activities; 1) identifying the complexity and novelty of the project and assessment of internal and external resources and knowledge stocks, 2) deploying the most suitable integration mechanism(s) for the identified complementarity type and 3) leveraging of the knowledge and experience learned/acquired during the project. Jointly, these three intertwined capabilities act as a complementarity management tool for product and process development managers, enabling them to manage their NPPD projects portfolios more effectively.
\end{abstract}

Keywords: Complementarity, Product Innovation, Process Innovation, Management Innovation, NPPD Project, Dynamic Capabilities 


\section{Introduction}

Since the initial academic interest in complementarity between product and process innovation (Abernathy and Utterback, 1978; Barras, 1986), much progress was made in understanding the concept (Ballot, Fakhfakh, Galia and Salter, 2015; Guisado-González, Wright and Guisado-Tato, 2017). The trend of favouring product innovation over process innovation in the innovation management literature has derailed towards the recognition that they are equal drivers of innovation activity, and their simultaneous consideration has significant benefits to the company (Damanpour, 2010; Martínez-Ros and Labeaga, 2009). Hullova et al. (2016) provided the most recent advancement in the conceptual development of complementarity management and proposed seven different extents of complementarities between product and process innovation in their 'Product-process complementarity map'. The map depicts a classification of complementarities (ranging from a low to high extent of complementarity) and was created as an aid for managers to help them choose the most suitable complementarity strategy for their current project.

The recent literature acknowledges the presence of different complementarity types in a company's portfolio of new product and process development (NPPD) projects. However, there is little empirical evidence on how to identify and manage different complementarity types at NPPD level and, the consequent codification and use of the newly acquired knowledge for a firm's benefit (Adegbesan, 2009; Ennen and Richter, 2010; GuisadoGonzález et al., 2017). Furthermore, Lager (2017)'s and Van Donk and Fransoo (2006)’s criticism of a lack of management innovation tools developed for process industries, among which the topic of complementarity management is particularly relevant, further underpins the limitations of current research. In process industries, product concepts require changes to the production processes, while the process development results in changes in features of the 
final product (Lager, 2011). To be able to manage this complementarity, companies are required to adopt new set of management tools and processes that consider this interdependence between product and process instead of using the existing ones that were developed for and, are widely used in industries producing assembled products (Frishammar, Lichtenthaler and Kurkkio, 2012).

This under-researched topic is often perceived as complex and firms within process industries are often referred to as too 'complicated' (Lager, Blanco and Frishammar, 2013). Therefore, for this study, we have chosen to examine complementarity management in NPPD projects within the food and drink processing industry. We believe that this industry is less complicated when compared to other process industries, and many scholars and practicing managers are already familiar its many products and production processes. Furthermore, companies in this industry instead of pursuing a few large innovation projects focus on undertaking a large number of NPPD projects that lead to rather incremental innovations. This makes the study of complementarity less complex, making the complementarity management easier to study (i.e., the lifecycle of NPPD projects in the food and drink industry is shorter when compared to other process industries) and leads to better visualisation and synthesis of findings. Besides, the food and drink industry is the UK's largest manufacturing sector and as such forms an important part of the UK's economy. Despite this, it does not receive much attention from academics and policymakers. However, recently, this interest started to grow because over the past decade the UK's food and drink industry has been facing decreasing innovation rates, low automation and shortages of a skilled workforce (Baker, 2013; Bigliardi and Galati, 2013; Capitanio, Coppola and Pascussi, 2010). Companies operating in this industry introduce over 8,000 new products to the market every year (FDF, 2018), but this number represents only about 20 per cent of all products 
developed (Ryynänen and Hakatie, 2012). In essence, only one in five products developed every year has a potential to end up in customers' shopping bags. Ryynänen and Hakatie (2012) claim that one of the main reasons for this low rate of success is the fact that most fundamental practices and principles of NPD are claimed to be common across most industries. In other words, the project management tools and processes pioneered and used by some industries (i.e., high technology industries) are not always appropriate to be used by companies operating in other industries. In line with Ryynänen and Hakatie (2012), we argue that due to the unique characteristics of food and drink industry and their broad portfolio of NPPD projects they need to deploy different project management tools to effectively manage different types of complementarities. Therefore, the purpose of our article is to provide theoretical insights and practical guidance that answer the following question:

How should firms operating in the food and drink industry effectively manage new product and process development projects with different extents of complementarity between product and process innovation?

We use Hullova et al.'s (2016) classification of complementarities to identify and investigate four case studies of NPPD projects. Each case study demonstrates a different type of complementarity, its key characteristics and its impact on project execution. The in-depth study and the further synthesis of these four cases allowed us to establish the key capabilities that firms needed to develop to successfully manage different types of complementarities across a broad range of NPPD projects. To provide a context and direction to our study, as well as to ground it in the existing theory, we use dynamic capabilities theory (Eisenhardt and Martin, 2000) and contingency theory (Donaldson, 2001), as our sensitising concepts (Blumer, 1954; Bowen, 2006). In essence, these theories serve us as a general sense of reference and guidance. By using the contingency theory, we establish different types of 
complementarities in NPPD projects, while the dynamic capabilities theory enables us to discover, understand and interpret similarities in their management. In particular, our paper builds on the work of Eriksson (2014, pp. 69-71), who in his synthesis of research findings on dynamic capabilities identified four focal elements of dynamic capabilities: (1) knowledge accumulation; (2) knowledge integration; (3) knowledge utilisation and, (4) knowledge reconfiguration.

From our findings, we develop a holistic framework for complementarity management between product and process innovation in NPPD projects. The framework consists of three interrelated capabilities and associated activities: 1) identifying the complexity and novelty of the NPPD project, with assessment of internal and external resources and knowledge stocks; 2) deploying the most suitable integration mechanism(s) for the identified complementarity type; and 3) the leveraging of the knowledge and experience learned during the NPPD project immediately, in the short-term or long-term. Furthermore, we develop five propositions, which combine characteristics of different complementarity types with the particularities of their management and these are further integrated into the proposed framework. Our framework provides a starting point in the area of complementarity management tools explicitly developed for NPPD project management in the food and drink industry. In particular, we provide evidence that there are significant differences among different complementarity types. Therefore, we argue that these complementarities need to be correctly identified before commencing the NPPD project. Doing so will allow project managers to deploy integration mechanism(s) that are the most appropriated for the identified complementarity type. Only when the complementary is correctly identified and managed, the firm can leverage the project outcomes and acquired learnings in the immediate, near and distant future. 
Lastly, our findings can also inform and shape the current formal and informal educational curriculum by providing a more systematic approach to managing NPPD projects with different types of complementarity. Therefore, this can not only be adopted by firms when designing new training programmes for their existing and future project managers but, it can also be integrated into educational materials for specialised degrees in Food Engineering or Manufacturing. We believe that our paper provides valuable theoretical insights and practical implications that can help to addresses a new policy laid out in the Food and Drink Federation (FDF) Manifesto 2017 'to help create a highly skilled home-grown talent that drives innovation' (FDF, 2017, p. 7).

We structure the rest of the article as follows. Firstly, the literature review brings together three separate research streams; complementarities-in-use, integration mechanisms, and complementarities-in-performance. Secondly, the findings section provides in-depth empirical insights into three critical capabilities and associated activities for effective complementarity management across four different complementarity types. Thirdly, we discuss our findings and introduce five propositions that are then integrated into the framework for identifying, managing and leveraging complementarity between product and process innovation, followed by a section on future research recommendations. We conclude with an overview of our contributions along with managerial and policy implications. 


\section{Research context: The UK food and drink industry}

The food and drink industry is the largest manufacturing sector in the UK. It consists of 6,100 medium-sized enterprises (SME) that employ over 117,000 people and contributes $£ 28.2$ billion to the UK economy annually (FDF, 2017). Annually, the food and drink manufacturers bring over 8000 new products to the market, and their cumulative investment into innovation exceeds $£ 1$ bn a year (FDF, 2018). The food and drink industry belongs to the cluster of low technology process industries that are characterised with research and development (R\&D) intensity below 1\% (median figures) and include: the basic metals (1\%), food and drinks $(0.8 \%)$ along with pulp and paper industries $(0.7 \%)$ (Lager, 2011). However, over the past decade, this industry has been negatively influenced by a range of technological, economic and societal changes and started to lag behind other industries. Companies missed many opportunities due to their reluctance to adopt new technologies, invest into development programs and training for their workforce and, by over focusing on minimisation of production costs (Baker, 2013; Bigliardi and Galati, 2013; Capitanio, Coppola and Pascussi, 2010). Mainstream innovation research and policy focus on R\&D and technology spend as a primary measure of innovativeness and growth. However, as argued by Hirsch-Kreinsen (2015), this does not reflect the true nature of innovation within the food and drink industry, in which many innovation initiatives are non-R\&D based (i.e., management innovation, mergers and acquisitions and fixed investment) (Som, 2012). For instance, the importance of management innovation - defined as the introduction of new management tools and practices that facilitate organisational change (Damanpour, 2014) - is, however, under-researched in the context of low technology process industries (Hirsch-Kreinsen, 2015; Robertson et al., 2009).

Therefore, we argue that guidance for NPPD teams on how to effectively manage different types of complementarities within their broad projects portfolios is critical among the food and drink industry due to the interdependent nature of product and process innovation. In this 
article, we postulate that due to this unique characteristic of innovation processes in the food and drink industry, the traditional NPD tool such as Stage gate model does not always yield the desired outcomes (Cooper, 2008). While high technology industries producing assembled products widely use this model, the process industries are likely to require the different tool that considers the interdependence between product and process innovation.

Furthermore, companies in the food and drink industry work on a portfolio of projects, where more breakthrough innovations, with a high degree of risk and high extent of complementarity, are combined with 'safer' projects with a higher success ratio but low extent of complementarity (Bruch and Bellgran 2014). Every project within the portfolio is characterised by a different type of complementarity that is further influenced by a number of contingencies; i.e., existing internal knowledge in product and process development, emphasis on product and process innovation, project's level of innovativeness (Hullova et al., 2016). Therefore, in order to be able to manage these diverse types of complementarities in NPPD projects, project teams need to develop a set of dynamic capabilities to help them manage the contingencies in each project. Incorrect allocation of time and resources towards a project could not only lead to increased time-to-market but also ineffective deployment of a workforce and an overall increase in the cost of the project (Bellgran, 1998). 


\section{Literature review}

Research on complementarities spans several separate research streams without a holistic understanding of dynamic capabilities required for a successful complementarity management process. These include studies on a) uncovering complementarities between product and process innovation, referred to as complementarities-in-use (Damanpour, 2010; Damanpour and Gopalakrishnan, 2001); b) integration mechanisms to facilitate synchronous consideration of product and process innovation (Adler, 1995; Rosell, Lakemond and Wasti, 2014); and c) identifying benefits from simultaneous execution of product and process innovation, termed as complementarities-in-performance (Cassiman and Veugelers, 2006; Pisano and Wheelwright, 1995; Turkulainen and Ketokivi, 2012). In the following section, we draw together and systematically structure these diverse literature streams.

\subsection{Complementarities-in-use}

Complementarities generally occur when two activities reinforce each other in such a way that doing one activity increases the value of doing the other (Milgrom and Roberts, 1995). The research field investigating links between two sets of activities, arguing that one practice depends on the other was termed as complementarities-in-use (Ballot et al., 2015). The most recent theoretical advances in this field were contributed by Hullova et al. (2016), who criticised prior studies for examining complementarities between product and process innovation at the industry or company level. The authors argued that there is no 'single best complementarity strategy' and companies work on a portfolio of NPPD projects that have different aims and require a different set of resources and capabilities. They defined NPPD projects as projects, where the interdependent nature between product and process innovation is recognised and managed. When compared to traditional NPD projects, where the product designers usually take the 'control of the process for uncovering and resolving design 
dependencies' (Swink, 2006, p. 38). In NPPD projects the most appropriate complementarity strategy is identified for the current project on the basis of its relative emphasis on product innovation and process innovation, which determines the extent of complementarity between them (Hullova et al., 2016). With an aim to provide a starting point in this research area, they synthesised existing literature on complementarities between product and process innovation and developed a classification of complementarities that occur at the NPPD project level and illustrated it in a conceptual framework 'Product-process complementarity map.' The map serves as a project portfolio management tool helping project managers to choose the most suitable complementarity strategy for current projects. We adopted the framework from Hullova et al. (2016), to facilitate readers' understanding of four main complementarity types Pooled, Amensalism, Sequential and Reciprocal complementarity and associated subcategories, see Figure 1.

Product Pooled and Process Pooled complementarities represent the lowest extent of complementarity between product and process innovation and occur when one innovation type has no or minimal impact on the other type of innovation (e.g., Traill and Meulenberg, 2002; Weiss, 2003). These projects are characteristic by effective utilisation of existing internal resources and firms' unwillingness to make more substantial investments to produce a product or improve a production process. In the food industry, Product Pooled complementarity is often seen in incremental changes to product components such as new flavours, ingredients or quality to meet consumer needs. In such projects, capabilities and existing knowledge of product developers and operation engineers are often sufficient (Hirsch-Kreinsen, 2008). Product Amensalism and Process Amensalism complementarities are characteristic with complacent technology trajectories, where a high path-dependency and focus on incremental innovation activities impedes the development of a high extent of 
complementarity between product and process innovation. For instance, in the food and drink industry manufacturers are often reluctant to pass away the preceding investments into existing production equipment that have been in use for 30-40 years, hindering their ability to produce more radical product innovations (Baker, 2013). Product Sequential and Process Sequential complementarities are characteristic with a dominant focus on either product or process innovation, which sequentially triggers changes to the complementary innovation type (e.g., Damanpour and Gopalakrishnan, 2001; Kurkkio, Frishammar and Lichtenthaler, 2011). For example, teams working on projects with Product Sequential complementarity often follow principles laid out in Cooper's Stage-Gate model (Cooper, 2008) and focus primarily on the development of a product concept and assessment of its feasibility. Only later stages start to consider the required changes to the production processes. While the Product Sequential complementarity is associated with an increased time to market, it is prevalent in more radical innovation projects. The highest extent of complementarity was termed as Reciprocal complementarity and refers to a synchronous adoption of product and process innovation (e.g., Lim, Garnsey and Gregory, 2006; Reichstein and Salter, 2006). Given the novelty and complexity of these projects, product and process teams work closely together from the beginning of the project and rely significantly on the external sources of resources and capabilities. Although the knowledge gained from prior NPPD projects is beneficial, the application of new management processes is necessary. 


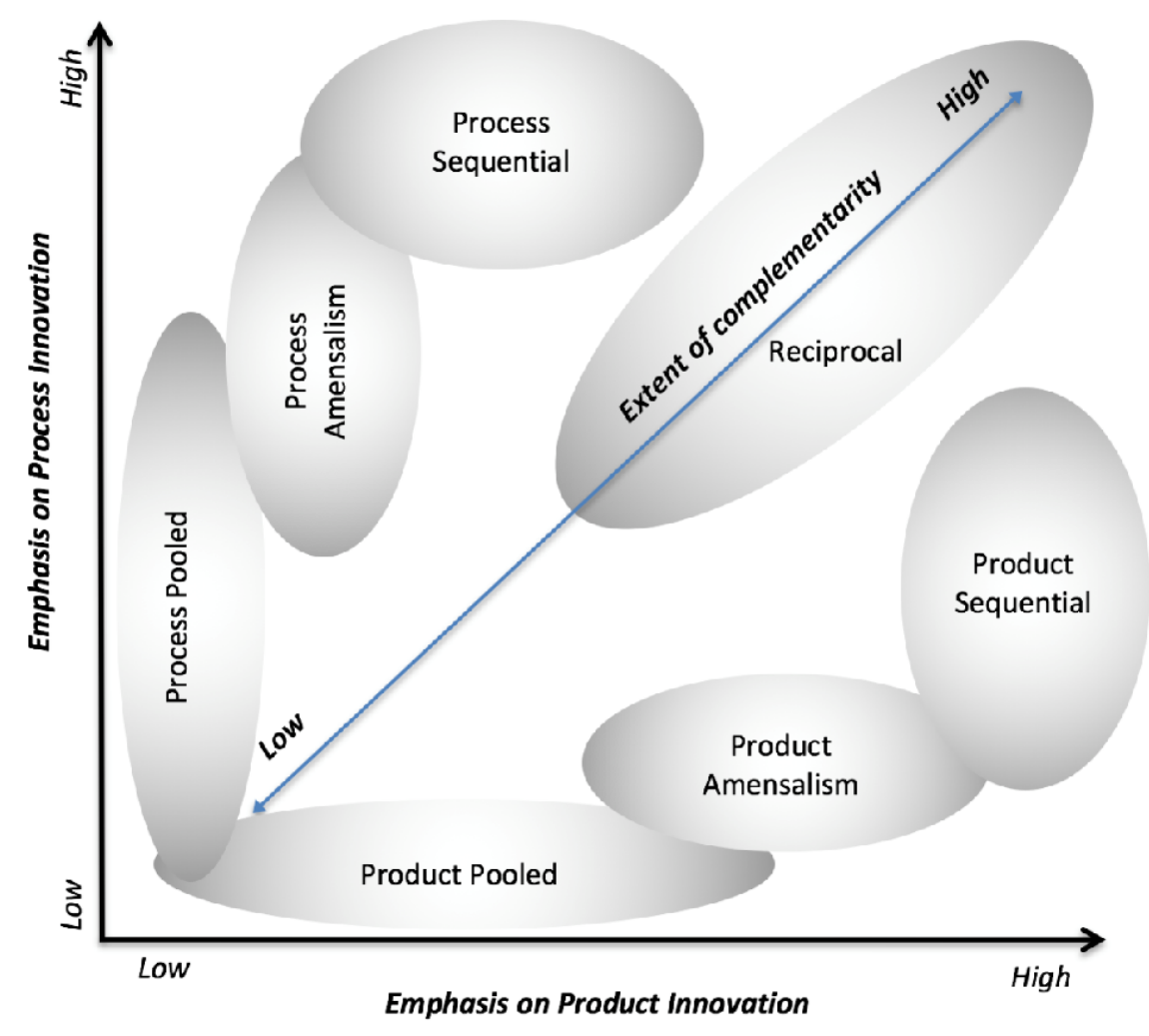

Figure 1. Product-process complementarity map to position a portfolio of projects (Adopted from Hullova et al., 2016, p. 934)

\subsection{Integration mechanisms}

Effective management of complementarity between product and process innovation requires the deployment of suitable management processes. Factors facilitating management of complementarity between product and process innovation are commonly referred to as 'integration mechanisms.' Integration can be described as 'process involving collaboration or co-operation and exchange of information" among distinct business functions (Säfsten et al., 2014, p. 219). Thus, integration is the process of achieving unity of efforts among subsystems in the accomplishment of the organisation's tasks (Lawrence and Lorsch, 1967). Vandevelde and Van Dierdonck (2003) argue that the nature of a project determines the level of required integration and the choice of integration mechanisms that need to be deployed. This implies that the nature of a project influences the level of integration between product and process 
innovation sought by firms (Adler, 1995). Project complexity and project novelty were identified as antecedents requiring the development of a relationship between different intercompany departments. Complexity and novelty add to the uncertainty, risk, and speed with which companies can introduce new products (Ragatz et al., 2002). However, when the achieved levels of integration are less than the ideal levels, the lack of coordination and planning will result in poor performance. On the other hand, once achieved levels of integration are higher than ideal levels the innovation success will be negatively affected and valuable resources wasted (Song and Thieme, 2006).

The existing literature has referred to integration mechanisms between product innovation and production (Turkulainen and Ketokivi, 2012; Vandevelde and Van Dierdonck, 2003; Wheelwright and Clark, 1994), product design and manufacturing (Ettlie, 1995; Kim et al., 1992) and product and process design (Adler, 1995). These studies, however, originate from different research fields, with few empirical contributions from the past decade against which to compare. This fragmentation was one of the reasons for publication of a Special Issue on 'Managing the Manufacturing - R\&D Interface' in the Journal of Manufacturing Technology Management, where authors aimed to bridge the gap between these fields (Lager and Rennard, 2014).

With a similar goal in mind, we developed Table 1., which provides an overview of the most commonly cited integration mechanisms, including their characteristics and benefits. We divided these mechanisms into three main types: cross-functional collaboration, coordination between product and process design, and interfacial management. Majority of studies summarised in Table 1 were conducted in high-technology industries, and our knowledge of integration mechanisms needed for complementarity management in low-technology process 
industries remains limited. For instance, the Quality Function Deployment (QFD), initially

published by Akao (1990) in Japan, achieved a high level of popularity in the USA and

Europe in the 1980s and is still commonly applied by car manufacturers, i.e., Toyota (Lager, 2011). Lager (2016, p. 465) termed the retrievable and accumulated platform of product and process knowledge as the 'hidden gem' of the QFD methodology. However, he questioned its applicability in the process industries, as within these industries assembled products are not produced. This led him to the development of the Multiple Progression QFD systems (mpQFD) as a facilitating tool in product and process innovation in process industries. The system illustrates how the Process, Product and Raw-material Matrices are applied to develop an integrated platform for further development of related product and process concepts (Lager, 2005).

\begin{tabular}{|c|c|c|}
\hline $\begin{array}{l}\text { Overarching } \\
\text { category }\end{array}$ & $\begin{array}{l}\text { Integration } \\
\text { mechanism }\end{array}$ & Definition, key characteristics and benefits \\
\hline \multirow[t]{3}{*}{$\begin{array}{l}\text { Cross-functional } \\
\text { collaboration }\end{array}$} & $\begin{array}{l}\text { Collaboration } \\
\text { between product } \\
\text { and production } \\
\text { engineers }\end{array}$ & $\begin{array}{l}\text { Cross-functional collaboration refers to the extent of collaboration and } \\
\text { representation of product and production engineers in the new product } \\
\text { development project (Turkulainen and Ketokivi, 2012). } \\
\text { Engineering designers, who take into consideration the production situation, } \\
\text { positively influence the development of the product/production interface } \\
\text { (Vandevelde and Van Dierdonck, 2003). }\end{array}$ \\
\hline & Integrator & $\begin{array}{l}\text { A core group of individuals that possesses relevant knowledge and skills in the } \\
\text { necessary areas and helps to ensure stability of a project when developing a } \\
\text { new product. Integrators are responsible for keeping both design and } \\
\text { manufacturing perspectives in balance (Wheelwright and Clark, 1994). }\end{array}$ \\
\hline & $\begin{array}{l}\text { Knowledge } \\
\text { integration } \\
\text { between buyer } \\
\text { and supplier }\end{array}$ & $\begin{array}{l}\text { Increased level of knowledge integration between buyer and supplier can } \\
\text { provide input to align the supplier's manufacturing process and product } \\
\text { technology expertise to the buyer's product development (Rosell et al., } 2014 \text {. } \\
\text { Lager and Storm (2013) referred to such practice as application development. }\end{array}$ \\
\hline \multirow[t]{2}{*}{$\begin{array}{l}\text { Coordination } \\
\text { between product } \\
\text { and process design }\end{array}$} & $\begin{array}{l}\text { Design for } \\
\text { manufacturing } \\
\text { and assembly } \\
\text { (DFMA) }\end{array}$ & $\begin{array}{l}\text { DFMA is a "systematic procedure for analyzing a proposed design from the } \\
\text { point of view of assembly and manufacture". The tool encourages dialogue } \\
\text { between designers and the manufacturing engineers...teamwork is encouraged } \\
\text { and benefits of simultaneous engineering can be achieved (Boothroyd, } \\
\text { Dewhurst and Knight, 2001, p. 22). } \\
\text { DFMA allows companies to estimate both assembly and part manufacturing } \\
\text { cost at the early stages of product design, shorten the time-to-market and } \\
\text { improve the quality and reliability of the product (Boothroyd et al., 2001). }\end{array}$ \\
\hline & $\begin{array}{l}\text { Concurrent } \\
\text { engineering (CE) }\end{array}$ & $\begin{array}{l}\text { The role of CE strategies is to organise and coordinate 'all the processes } \\
\text { towards minimum lead time and development cost, while maintaining product } \\
\text { quality to the total satisfaction of the customer' (Nategh, 2009, p. 5147). }\end{array}$ \\
\hline
\end{tabular}




\begin{tabular}{|c|c|c|}
\hline & $\begin{array}{l}\text { Quality function } \\
\text { deployment } \\
(Q F D)\end{array}$ & $\begin{array}{l}\text { QFD process enables 'an organisation to build quality into a product and } \\
\text { control the development process from conception to the commencement of } \\
\text { manufacturing operations' (Chen, 2009, p. 1471). } \\
\text { Several different versions of QFD have been developed such as the 'House of } \\
\text { Quality' (Akao and Mazur, 2003), an mpQFD system adapted for process } \\
\text { industries (Lager, 2011; Lager, 2016) and the 'Matrix of Matrices' (Akao, } \\
\text { 1990). } \\
\text { It has proven to enable companies to develop links between development } \\
\text { cycles, ensuring that requirements of all 'customers' in the product design } \\
\text { process are taken into account, including downstream users in the company, } \\
\text { end users, suppliers, etc. (Akao, 1990; Wheelwright and Clark, 1994). }\end{array}$ \\
\hline \multirow[t]{2}{*}{$\begin{array}{l}\text { Interfacial } \\
\text { management }\end{array}$} & $\begin{array}{l}\text { Transfer } \\
\text { synchronisation }\end{array}$ & $\begin{array}{l}\text { Rich and bilateral communication and effective integration between product } \\
\text { and process team are essential in the integrated problem solving (Säfsten et al., } \\
\text { 2014; Wheelwright and Clark, 1994). }\end{array}$ \\
\hline & $\begin{array}{l}\text { Formal } \\
\text { organisation }\end{array}$ & $\begin{array}{l}\text { Highly complex projects benefit from formal product development processes } \\
\text { and structured ways of working. A well-structured transfer process facilitates } \\
\text { the transfer from product to production, making the knowledge more efficient } \\
\text { to exploit, apply and implement (Adler, 1995; Nobelius, 2004; Vandevelde and } \\
\text { Van Dierdonck, 2003). }\end{array}$ \\
\hline
\end{tabular}

Table 1. An overview of integration mechanisms including their key characteristics and benefits

\subsection{Complementarities-in-performance}

Effective complementarity management does not only provide immediate yields such as reduced development time during execution of the NPPD project but can also lead to overall improvement of company's innovation performance (Ballot et al., 2015; Martínez-Ros and Labeaga, 2009). The stream of research examining these benefits was in the innovation management field, termed by Ballot et al. (2015) as complementarities-in-performance. Researchers in this field focused on identifying the economic benefits of combining different management practices, proving that their joint application leads to greater advantages than the individual parts (Ballot et al., 2015).

For instance, Pisano and Wheelwright (1995) found that manufacturing process innovation goes hand in hand with product innovation and enables companies to launch new products faster, more frequently and effectively. In complex projects, product manufacturability, the lead time for the production system development and the entire product realisation process 
can be improved by the early planning of machine and equipment investments, design of work organisation and material supply system (Bellgran and Säfsten, 2010; Eppinger, 1991). However, inability to develop product and production system simultaneously due to inefficient resource allocation, and the inability to foresee different complications and resolve them in an efficient manner, could result in significant project delays (Bellgran, 1998).

Meanwhile, Wheelwright and Clark (1994) found that a competitive advantage can be achieved if companies can consistently, over a series of projects, accelerate the design-buildtest cycle. The learning process and knowledge accumulated during execution of one project can be re-used in development of an alternative innovation, positively influencing the innovation performance of the company and leading to economies of scale (Martínez-Ros and Labeaga, 2009). In the low technology environments, such as the food and drink industry, successful innovation process can be explained in the form of practical and pragmatic ways by 'learning-by-doing, by-using, and by interacting' (DUI), where extensive on-the-job problem solving occurs and project teams interact and share experience (Thomä, 2017; Trott and Simms, 2017). Following a literature review of the most commonly cited articles in this field, we classify complementarity benefits between product and process innovation into three distinct categories: competitive advantage; efficiency; and launch of new products (see Table 2.).

\begin{tabular}{|c|l|}
\hline \multicolumn{1}{|c|}{ Benefit category } & \multicolumn{1}{c|}{ Type of benefit } \\
\hline \multirow{3}{*}{ Competitive advantage } & $\begin{array}{l}\text { Long lasting competitive advantage though accelerated design-build-test cycle } \\
\text { (Wheelwright and Clark, 1994) } \\
\text { Overall improvement of company's innovation performance (Ballot et al., 2015; } \\
\text { Damanpour and Gopalakrishnan, 2001; Martínez-Ros and Labeaga, 2009; Pisano, 1997) } \\
\text { Protection of the company from imitation by creating complex innovation strategies } \\
\text { (Rivkin, 2000; Turkulainen and Ketokivi, 2012) }\end{array}$ \\
\hline
\end{tabular}




\begin{tabular}{|l|l|}
\hline Efficiency & $\begin{array}{l}\text { Ease of production ramp-up process (Pisano 1997; Pisano and Wheelwright, 1995) } \\
\text { Ability to control product mix and acquire process equipment (Kim et al., 1992) }\end{array}$ \\
\hline \multirow{2}{*}{ Launch of new products } & $\begin{array}{l}\text { A smoother launch of new products (Bruch and Bellgran, 2014; Kotabe and Murray, } \\
1990 ; \text { Pisano and Wheelwright, 1995) } \\
\text { More producible and higher quality products (Swink and Calantone, 2004) }\end{array}$ \\
\hline
\end{tabular}

Table 2. Benefits achieved by effective management of complementarity between product and process innovation in NPPD projects

In essence, the literature review sections provided insights into our current understanding of complementarities-in-use, integration mechanisms, and complementarities-in-performance.

They are separate streams of research, and this was perhaps one of the main reasons why, to date, no study has provided holistic insights into how managers responsible for NPPD projects with different extents of complementarity identify and manage different complementarity types and at the same time leverage benefits of these practices during and after the project. These three streams provide a starting point for our data collection and analysis. 


\section{Methodology}

The complex nature of complementarities between product and process innovation often resulted in conceptual contributions at the industry level (Abernathy and Utterback, 1978) and studies based on large-scale surveys, i.e., Community Innovation Survey (Ballot et al., 2015; Battisti and Stoneman, 2010). A limited number of empirical studies and a lack of more granular insights on complementarity management at the NPPD project level led us to use abductive multiple case study design (Edmondson and McManus, 2007; Flyvberg, 2006; Quintens and Matthyssens, 2010).

We built on the logic of purposeful sampling (Patton, 1990) and selected rich cases to gain an in-depth understanding of the management of NPPD projects with different extents of complementarities between product and process innovation. Following the initial analysis of all the projects within our case study database, we selected four projects that represented a spectrum of complementarities. We aimed to provide insights into a broad range of complementarities occurring in NPPD projects in the food and drink industry. From our database of nine cases that were collected across six companies, we decided to include four case studies of NPPD projects that represent four different types of complementarities for the following reasons: a) the complementarity type and its management were well-documented and clearly observable; b) the project was representative of company's respective project portfolio, c) projects were finalised at least two years before our investigation to enable us to observe time-related phenomena and understand future applications of accumulated knowledge from investigated projects. This would not be possible if the projects were at their beginning, in the middle of development or recently finished. We believe that we would not be able to gain such in-depth insights if we chose projects through a random selection, as is common in quantitative studies, where the assumption is that anyone observation is more 
important than others (Dubois and Araujo, 2007). Table 3. presents an overview of selected case studies resembling four extents of complementarities between product and process innovation (Reciprocal, Product Sequential, Process Amensalism and Process Pooled complementarity). The cases were selected from a range of large and medium-sized branded food and drink processing companies and include a dairy, a brewery, snacks manufacturer and a processed food manufacturer. The level of companies' innovativeness was directly proportional to their $R \& D$ investment. The higher was the $R \& D$ investment of the company, the more innovative NPPD projects the company had in its project portfolio. For instance, the snacks and processed food manufacturers focused on incremental product and process innovations (i.e., changing flavours, sizes of their products, enhancement of the existing recipes and efficiency of the production line). Their project portfolios were centered around projects with a low extent of complementarity and their investment into R\&D was very low. On the other hand, the dairy and the brewery due to their large R\&D budgets devoted more time to radical innovations and NPPD projects. Their project portfolios were scattered across high and low extent of complementarity, resembling ambidextrous innovation. 


\subsection{Data collection}

Findings presented in this paper are part of a broader 3-year research project focused on examining the complementarity management between product and process innovation in NPPD projects in the UK food and drink industry. Our data collection was divided into two phases. The second, main case study data collection, was preceded by a pre-study. In the prestudy, informants were selected based on their expert knowledge and experience in the development of new products, packaging, and production processes within the UK food and drink industry (i.e., senior managers, process development managers, product development managers, innovation managers, packaging experts, and consultants). The aim was to get a broad representation of informants across a range of companies operating in the food and drink industry. Informants were identified through existing gatekeepers, and at a range of food and drink exhibitions and trade events organised annually in London. During the interviews we discussed participants' attitudes towards product and process innovation independently, followed by the discussion on management of complementarities in NPPD projects. At the end of each interview, informants were presented with the Product-process complementarity positioning map developed by Hullova et al. (2016). The interviewer described the complementarity types on the basis of definitions included in Hullova et al. (2016) and further detailed in Hullova (2017). Afterward, participants were asked to identify projects that resembled different types of complementarities described within the developed constructs. Successfully executed projects were discussed and identified after a thorough examination of each project's characteristics. We were seeking insights into poorly understood phenomena, the map enabled our participants to understand the concept of complementarity, and hence they were 'better equipped' to allocate different NPPD projects on the basis of different complementarity types and lead to a fruitful discussion with the researcher (Dubois and Araujo, 2007). We acknowledge that management of complementarity 
in each case study may have been influenced by several contextual contingencies (i.e.,

financial constraints, time, collaboration with external parties). However, we believe that by

using the Map as an established theoretical concept we were able to identify the pattern

(complementarity type) in specific cases (Halkier, 2011; Søndergaard, 2002) and hence, we

postulate that our findings are analytically generalisable (Yin, 2009).

\begin{tabular}{|c|c|c|c|c|c|}
\hline $\begin{array}{c}\text { Complementarity } \\
\text { types with } \\
\text { definitions } \\
\text { adapted from } \\
\text { Hullova et al. } \\
\text { (2016) }\end{array}$ & $\begin{array}{l}\text { Projects (in order } \\
\text { of extent of } \\
\text { complementarity } \\
\text { - from high to } \\
\text { low) }\end{array}$ & $\begin{array}{c}\text { Aim of the } \\
\text { project }\end{array}$ & $\begin{array}{c}\text { Product } \\
\text { developments }\end{array}$ & $\begin{array}{c}\text { Process } \\
\text { developments }\end{array}$ & $\begin{array}{l}\text { Rationale for the } \\
\text { complementarity choice } \\
\text { (quotes from pre-study } \\
\text { respondents) }\end{array}$ \\
\hline $\begin{array}{l}\text { Reciprocal } \\
\text { Synchronous } \\
\text { adoption of } \\
\text { product and } \\
\text { process innovation }\end{array}$ & $\begin{array}{l}\text { Draught beer } \\
\text { Development of a } \\
\text { radically new } \\
\text { product technology } \\
\text { synchronised with } \\
\text { significant changes } \\
\text { to the existing } \\
\text { production } \\
\text { equipment }\end{array}$ & $\begin{array}{l}\text { Deliver the } \\
\text { experience } \\
\text { of frothy } \\
\text { head on the } \\
\text { beer from } \\
\text { the tap } \\
\text { served in } \\
\text { pubs in the } \\
\text { take-home } \\
\text { market in } \\
\text { cans. }\end{array}$ & $\begin{array}{l}\text { Design and } \\
\text { development } \\
\text { of an insert } \\
\text { (product } \\
\text { technology) } \\
\text { that would } \\
\text { create a foam } \\
\text { head on the top } \\
\text { of the beer } \\
\text { once poured } \\
\text { from can into a } \\
\text { glass. }\end{array}$ & $\begin{array}{l}\text { Significant } \\
\text { adjustments to } \\
\text { the existing } \\
\text { filling and } \\
\text { canning line. }\end{array}$ & $\begin{array}{l}\text { "The development of the } \\
\text { froth forming technology } \\
\text { [insert] had to be } \\
\text { synchronised with a heavy } \\
\text { modification of the } \\
\text { conventional canning } \\
\text { line ...we could not have } \\
\text { come up with a solution for } \\
\text { the insert without a tight } \\
\text { relationship between } \\
\text { packaging and process } \\
\text { innovation." (General } \\
\text { manager) }\end{array}$ \\
\hline $\begin{array}{l}\text { Product } \\
\text { Sequential } \\
\text { The dominant } \\
\text { focus on product } \\
\text { innovation triggers } \\
\text { changes in process } \\
\text { innovation }\end{array}$ & $\begin{array}{l}\text { UHT milkshake } \\
\text { Development of a } \\
\text { product and } \\
\text { packaging concept } \\
\text { led to adjustments } \\
\text { to the setting of the } \\
\text { processing and } \\
\text { filling machines at } \\
\text { the third-party co- } \\
\text { packer }\end{array}$ & $\begin{array}{l}\text { Extend the } \\
\text { shelf-life } \\
\text { of the } \\
\text { existing } \\
\text { fresh } \\
\text { milkshake } \\
\text { product to } \\
\text { sell it } \\
\text { through } \\
\text { garages } \\
\text { and petrol } \\
\text { stations. }\end{array}$ & $\begin{array}{l}\text { Development } \\
\text { of UHT } \\
\text { version of } \\
\text { existing fresh } \\
\text { milkshake. } \\
\text { Development } \\
\text { of a novel } \\
\text { three-layered } \\
\text { bottle to } \\
\text { protect the } \\
\text { milkshake } \\
\text { from light. }\end{array}$ & $\begin{array}{l}\text { Adjustments to } \\
\text { the settings of } \\
\text { the processing } \\
\text { and filling } \\
\text { machines at the } \\
\text { third-party co- } \\
\text { packer. } \\
\text { Development } \\
\text { of a new } \\
\text { custom-made } \\
\text { packing line at } \\
\text { the third-party } \\
\text { co-packer. }\end{array}$ & $\begin{array}{l}\text { "The project started with a } \\
\text { need to develop UHT version } \\
\text { of the existing milkshake } \\
\text { product ... lab tests were } \\
\text { done to check whether the } \\
\text { project would be feasible ... } \\
\text { the packaging and } \\
\text { processing lines were there } \\
\text { however, this new project } \\
\text { would require a significant } \\
\text { upgrade of the existing } \\
\text { production that would } \\
\text { involve a significant amount } \\
\text { of investment... the } \\
\text { purchasing team contacted } \\
\text { co- packer who was already } \\
\text { producing UHT milk... we } \\
\text { worked together to adjust } \\
\text { their production to fit our } \\
\text { milkshake ... it was a much } \\
\text { cheaper solution than } \\
\text { producing the product in- } \\
\text { house." (Marketing } \\
\text { manager) }\end{array}$ \\
\hline
\end{tabular}




\begin{tabular}{|c|c|c|c|c|c|}
\hline $\begin{array}{l}\text { Process } \\
\text { Amensalism } \\
\text { Existing } \\
\text { production } \\
\text { equipment hinders } \\
\text { the development of } \\
\text { new products }\end{array}$ & $\begin{array}{l}\text { Mini-wafers } \\
\text { The existing } \\
\text { production } \\
\text { equipment } \\
\text { constrained } \\
\text { product } \\
\text { development- } \\
\text { allowed only the } \\
\text { production of } \\
\text { smaller size } \\
\text { product }\end{array}$ & $\begin{array}{l}\text { To respond } \\
\text { to the } \\
\text { increasing } \\
\text { popularity } \\
\text { in baked } \\
\text { savoury } \\
\text { snacks and } \\
\text { minificatio } \\
\mathrm{n} \text { trend. }\end{array}$ & $\begin{array}{l}\text { Production of a } \\
\text { mini version of } \\
\text { the existing } \\
\text { Jalapeno wafer. }\end{array}$ & $\begin{array}{l}\text { Production of a } \\
\text { plastic tray } \\
\text { with a higher } \\
\text { number of } \\
\text { holes and a } \\
\text { smaller size } \\
\text { that was added } \\
\text { to the existing } \\
\text { production line } \\
\text { used for } \\
\text { production of } \\
\text { standard } \\
\text { wafers. }\end{array}$ & $\begin{array}{l}\text { "We had to work within } \\
\text { constraints of the line used } \\
\text { for the production of wafers } \\
\text { [existing product] ... we only } \\
\text { wanted to introduce smaller } \\
\text { version of the same product } \\
\text { [mini-wafers] however, our } \\
\text { existing equipment did not } \\
\text { allow us to do that. } \\
\text { [Therefore] ... we } \\
\text { approached a local } \\
\text { engineering company that } \\
\text { was able to help us by } \\
\text { developing a new add-on } \\
\text { equipment that we were able } \\
\text { to integrate into our existing } \\
\text { production line" (Production } \\
\text { manager) }\end{array}$ \\
\hline $\begin{array}{l}\text { Process Pooled } \\
\text { Process innovation } \\
\text { takes place with } \\
\text { minimal or } \\
\text { unintentional } \\
\text { impact on product } \\
\text { innovation }\end{array}$ & $\begin{array}{l}\text { Canned minced } \\
\text { beef } \\
\text { Production } \\
\text { efficiency } \\
\text { enhancement } \\
\text { through } \\
\text { incremental } \\
\text { process innovation } \\
\text { led to product } \\
\text { quality } \\
\text { enhancement }\end{array}$ & $\begin{array}{l}\text { Enhanceme } \\
\text { nt of the } \\
\text { efficiency } \\
\text { of the } \\
\text { cooking } \\
\text { process. }\end{array}$ & $\begin{array}{l}\text { Product quality } \\
\text { was enhanced } \\
\text { as an } \\
\text { unintentional } \\
\text { by-product } \\
\text { (was not } \\
\text { marketed as an } \\
\text { innovation). }\end{array}$ & $\begin{array}{l}\text { Decrease the } \\
\text { steam pressure } \\
\text { on the cookers' } \\
\text { settings from } 4 \\
\text { to } 2 \text { bars. }\end{array}$ & $\begin{array}{l}\text { "Lowering the bar pressure } \\
\text { from } 4 \text { to } 2 \text { bars [during the } \\
\text { steam injection process] in } \\
\text { the minced meat project } \\
\text { enabled us to improve } \\
\text { overall equipment efficiency } \\
\text { by } 30 \% \text {... keeping the piece } \\
\text { integrity of meat and } \\
\text { vegetables [higher quality } \\
\text { product]" (NPD manager) }\end{array}$ \\
\hline
\end{tabular}

Table 3. Complementarity type, product, process developments and project aims from four illustrative case studies

In order to build upon the initial data collection, we undertook a second phase of interviews with informants, who were involved in the selected NPPD projects. Semi-structured interviews with key informants from multiple functional areas were undertaken for each project. We were interested in talking to informants involved in the R\&D of product and process innovation and management of innovation in NPPD projects. Therefore, in some cases, suppliers of production equipment or key external collaboration parties that were involved in the projects were consulted to provide further insights and greater understanding of the particular case (see Appendix 1.). This information enabled us to provide context and enrich respondents' answers, leading to empirical triangulation (Sekaran and Bougie, 2016). The format of interviews was adapted to the type of respondent's involvement in the project 
to identify new and potentially fruitful points (Nag, Hambrick and Chen., 2007). Interviews lasted between 42 minutes and 2 hours and covered themes such as; allocation of existing and new resources towards the project, management of the product and process innovation and future opportunities that the NPPD project opened-up for the company. In addition, a short follow-up phone and email interviews with most participants took place over the course of the study to provide further details that were not covered during the previous interview(s). In essence, each interview, observation or reading of a secondary data source added an extra layer of understanding and enhanced our ability to observe new patterns in the data (Dubois and Gadde, 2002).

\subsection{Data analysis}

Our data analysis followed principles of systematic combining as described by Dubois and Gadde $(2002 ; 2014)$. With an aim to fully explore the theoretical and empirical phenomena, systematic combining was the most compelling approach as it enabled us to go 'back and forth' between different research activities, e.g., evolving framework, existing literature, theory and empirical data. Our study began with an exploratory aim to uncover management of different types of complementarities in NPPD projects. As empirical observations started to point to new patterns in the data that were not covered by the existing literature, we continued to explore these patterns. This simultaneously influenced the sensitising concepts that were used to understand the data- dynamic capabilities and the contingency theory. Subsequently, insights that resulted from unanticipated data led to further evolution and changes to the framework (Dubois and Gadde, 2002). 
The data collection and analysis took place simultaneously. All interviews were transcribed and complemented with email communications, documents (i.e., press releases and internal documents), our observations and meeting notes. The first stage in our data analysis focused on rereading the interview transcripts several times, marking phrases, terms, sections that expressed the informants' views in their own words. The process of pre-coding gave rise to provisional codes, some of these were 'validated' by an ongoing data collection and were adopted as core codes. The principal investigator put great emphasis on the clarity of such codes to aid collaboration with other members of the research team. The search for new codes (pre-codes, provisional codes, and final codes) occurred in line with the use of sensitising concepts to facilitate the generation of a new theory.

Consequently, memo-writing helped us to identify the properties of different concepts, connections among these and examine whether the data indeed illustrate the codes and concepts by asking how, why and what questions. The empirically derived framework is a result of matching between the existing literature on complementarities between product and process innovation, sensitising concepts, dynamic capabilities, and contingency theory. These, among others, emerged during the process of data collection as the most suitable for helping us to answer the research question. 


\section{Findings: Insights from NPPD projects illustrating four different types of complementarities}

The Findings section is divided into three parts; 1) capability to identify the complementarity

type, 2) capability to deploy a suitable integration mechanism(s), and 3) capability to leverage the developed/acquired knowledge and expertise in future NPPD projects. Each part draws on insights from four case studies that demonstrate different type of complementarity and provide insights into the management of these complementarities. To establish richer background on cases used in our study, and to provide more details on different approaches adopted in complementarity management, we include a comprehensive table at the beginning of each section. The following sections illustrate that despite significant differences among the complementarity types, the commonalities in their management exists. Firms wanting to successfully manage the NPPD projects with different extents of complementarity all need to develop three dynamic capabilities. These capabilities allow managers to correctly identify complementarity type present in the potential NPPD project, deploy a suitable integration mechanism, and consequently leverage acquired knowledge and experience immediately, in short-term and long-term. The identified capabilities are sequential and interdependent. Therefore, developing only one capability would not be sufficient for successful management of complementarity between product and process innovation in NPPD project.

\subsection{Capability to identify the complementarity type}

A shared characteristic of NPPD projects was the project managers' ability to appropriately identify level of complementarity. This had a positive impact on the execution of product and process developments as well as the assessment of the project's feasibility. The 
complementarity was primarily identified on the basis of:

a) assessment of complexity and novelty of product and process developments

b) accessible resources (internal and external) and knowledge stocks (skills, experience, tacit and explicit knowledge)

We provide an overview of findings from our four case studies in Table 4 to demonstrate the process through which the project managers aimed to identify the extent of complementarity in their NPPD projects. This capability closely resembles one of the focal elements of dynamic capabilities identified by Eriksson (2014), knowledge accumulation, that refers to company's ability to undertake internal experiential learning and collaborate with external sources of knowledge.

\begin{tabular}{|c|c|c|}
\hline \multicolumn{3}{|c|}{ Critical capability: Identifying the complementarity type } \\
\hline Activities & $\begin{array}{c}\text { Extent of } \\
\text { complementarity } \\
\text { in the NPPD } \\
\text { project (from high } \\
\text { to low) }\end{array}$ & Examples from case studies \\
\hline $\begin{array}{l}\text { 1. Identify the } \\
\text { complementarity type } \\
\text { of the project, based } \\
\text { on: } \\
\text { a) complexity and } \\
\text { novelty of the product } \\
\text { and process } \\
\text { developments } \\
\text { b) internal } \\
\text { resources/knowledge } \\
\text { required for product } \\
\text { development and } \\
\text { process development }\end{array}$ & $\begin{array}{l}\text { Reciprocal } \\
\text { (draught beer in a } \\
\text { can) }\end{array}$ & $\begin{array}{l}\text { 1a) Significant changes to the existing filling and canning lines as well } \\
\text { as development of a novel froth forming technology } \\
\text { 1b) Own filling and packing plant } \\
\text { - Froth development knowledge from the draught beer from the keg } \\
\text { project and numerous attempts to develop the product technology } \\
\text { internally } \\
\text { 1c) Plastic components company to help with design and development } \\
\text { of hollow disk (the product technology) } \\
\text { - Physicists and mathematicians from the Engineering Laboratory to } \\
\text { conduct modelling work and help to understand and fine-tune } \\
\text { technologies and processes involved } \\
\text { - Equipment suppliers to include five additional steps to the existing } \\
\text { conventional filling and canning lines }\end{array}$ \\
\hline $\begin{array}{l}\text { c) external } \\
\text { resources/knowledge } \\
\text { required for product } \\
\text { and process } \\
\text { development }\end{array}$ & $\begin{array}{l}\text { Product Sequential } \\
\text { (UHT milkshake) }\end{array}$ & $\begin{array}{l}\text { 1a) Development of UHT version of the existing milkshake product, } \\
\text { development of novel light-proof packaging } \\
\text { 1b) Resource management process was adopted to allocate the } \\
\text { expertise of existing employees towards the project } \\
\text { - Ability to undertake lab samples to verify the feasibility of the } \\
\text { project } \\
\text { - The dairy manufacturer did not have prior experience in producing } \\
\text { UHT product } \\
\text { 1c) Existing contacts of the internal innovation experts with external } \\
\text { organisations helped to identify; }\end{array}$ \\
\hline
\end{tabular}




\begin{tabular}{|l|l|l|}
\hline \multicolumn{1}{|l|}{} & $\begin{array}{l}\text { - A third-party co-packer in Spain with existing resources and } \\
\text { capabilities in filling and packing UHT milk } \\
\text { - Bottle manufacturer to develop a unique three-layered bottle to } \\
\text { prevent light passing through the bottle }\end{array}$ \\
\hline $\begin{array}{l}\text { Process } \\
\text { Amensalism } \\
\text { (mini-wafers) }\end{array}$ & $\begin{array}{l}\text { 1a) Minor development of the existing production equipment (through } \\
\text { a bolt-on goodie) to enable the production of a small version of } \\
\text { existing regular size jalapeno wafers }\end{array}$ \\
$\begin{array}{ll}\text { 1b) Knowledge to utilise the flexibility of the existing machine was } \\
\text { missing }\end{array}$ \\
\hline $\begin{array}{l}\text { 1c) Local engineering company to produce a plastic tray with a higher } \\
\text { number of holes with smaller sizes than the existing one }\end{array}$ \\
$\begin{array}{l}\text { Process Pooled } \\
\text { beef) }\end{array}$ & $\begin{array}{l}\text { 1a) Change to the production equipment settings was required } \\
\text { 1b) Knowledge about the impact of pressure processing on the quality } \\
\text { of minced meat (identified by front R\&D personnel through different } \\
\text { cooking methods) } \\
\text { - Operations staff to define and test suitable treatment conditions (bar } \\
\text { pressure/time) } \\
\text { - Knowledge also gained through prior collaboration with starch } \\
\text { companies } \\
\text { 1c) Collaboration with external parties was not required }\end{array}$ \\
\hline
\end{tabular}

Table 4. Identifying the complementarity type - an overview of findings from the four case studies

In the Reciprocal complementarity project, which represents the highest extent of complementarity, the brewery had learnt the froth development skills during the 'draught from keg' project. However, despite a significant amount of investment into research and development, patenting several different versions of the froth forming insert and having its own filling and canning plant, all of these attempts were short-lived and proved to be commercially unviable. In essence, the company had relevant knowledge and experience but this was not sufficient for executing the project. The development of a unique technology to produce draught beer from cans was too novel, and engineers with the $R \& D$ team had to admit that they are not able to achieve any significant success by limiting themselves to their internal resources and expertise. Under increasing competition from the lager-beer producers, the brewery decided to identify and collaborate with external parties to help the project team with the development of unique product technology, alongside changes to the manufacturing processes. Throughout the entire NPPD project, the brewery was highly dependant upon the 
expertise of external sources of knowledge. Plastic components company from an automotive sector helped the brewery to design and develop a pre-sealed insert containing gas under pressure (the product technology). Although, early on, this company was reluctant to get involved due to a high level of risk involved in the project. The brewery managed to convince them of the project's feasibility and market potential. The general manager commented on the complexity and novelty of the product technology:

"Firstly, we had to decide what would be the best technology to use in plastics [to produce the pre-sealed insert]. At that time, it was common to use heat thermoplastics and blow moulding ... Injection moulding technology that was selected in the end was a new technology and has proven to be the best for the project. It was a very diligent technical process."

The brewery also partnered with a government-funded research laboratory's physicists and mathematicians to conduct modelling work in order to understand all technologies and processes involved in the project. The laboratory helped the project team to answer all questions and identify possible weaknesses in functioning of the insert and the levels of $\mathrm{CO}_{2}$. Conventional filling and canning lines were heavily modified in collaboration with equipment suppliers to include five additional steps to accommodate the new product technology by maintaining the speed and efficiency of the line. Although the brewery was against significant changes to the existing production equipment, novelty of the product technology made such changes necessary. As stated by an ex-managing director:

"The company [brewery] was reluctant to invest into a completely new canning line, they wanted to make sure that the new technology will be compatible with the 
technology of the insert and it integrated with the existing packaging line without too many changes."

Early on, the company realised that it might struggle to integrate its new technology into the existing production processes. Building a new canning line that would accommodate a single product, that has been still in development, was infeasible because of the high uncertainty, cost and risk involved. Equally, the firm did not want to invest in the development of the new technology if its current processes could not accommodate it. Therefore, both new technology and potential changes to the existing canning line that this technology required were considered simultaneously. The project team recognised that the project would be full of iterative processes with many cycles and interconnections between product technology and changes to the existing production equipment. As well as the new technology was putting pressure on existing processes and demanding significant adjustments, the existing processes put many constraints on how the new technology was developed. Given the demands that new product development had on required processes and, constraints that existing processes put on new product development, both product and process were recognised as equally important from the early beginning of the project and thus, required Reciprocal complementarity management.

On the other hand, Process Pooled project portraying a low extent of complementarity built upon the existing tacit and explicit knowledge. This knowledge was acquired through learning-by-doing, using and interacting instead of being rooted in organisational processes and structures (formalised and codified) (Trott and Simms, 2017). The project team identified early on that the tacit internal knowledge of the R\&D personnel and experienced engineers that regularly collaborated with the Food Research Institute and starch companies were sufficient to enhance the efficiency of cookers. As stated by the interviewed NPD manager: 
"The opportunity for a process improvement was identified by the front $R \& D$ personnel in the kitchen through various cooking methods. Engineers were aware that when gelatinising the starch, the higher the pressure, the higher was the sheer effect on the colour, starches, and vegetables. By going to a lower pressure, the engineers could control the gelatinisation of starches better ... keeping the piece integrity of meat and vegetables."

Due to the low novelty and complexity of the project the primary aim in this project was to adjust the treatment conditions (bar pressure/time) of meat to increase the production efficiency of the existing cookers. By simple adjustment of pressure during the steam injection process from 4 bars to 2 bars and a slight increase in the processing time, the ready meals manufacturer was able to increase the overall equipment efficiency by 30 per cent. The pressure change had a positive effect on the quality of meat and vegetables, but it was not marketed as an innovation. In this project, the change in the production process did not require any changes to the product, as it is always the case with Reciprocal complementarity. The improvement in the quality of the product was not planned and, can be considered a 'byproduct' of the process innovation in the Process Pooled project.

\subsection{Capability to deploy suitable integration mechanisms}

Choice of integration mechanisms followed the assessment of complementarity type. Similarly, as with the identification of complementarity, determination of integration mechanisms differed by the extent of complementarity across the four case studies. Our study confirms the findings of Song and Thieme (2006), and provides further evidence that for NPPD project to be considered successful, managers need to turn the ideal complementarity 
into the achieved complementarity. In essence, this means that managers are required to choose the right integration mechanism(s) for the right complementarity type. If achieved complementarity differs from the one that was initially identified (ideal complementarity), this leads to significant inefficiencies in project management (Song and Thieme, 2006). To accomplish this, project managers need to be familiar with a broad range of integration mechanisms and their application. Our cases provide evidence that projects with a lower extent of complementarity used non-formal integration processes, where the company was building on trial-and-error experimentation. However, in the projects with higher extents of complementarity, application of more formal integration mechanisms (or their combination) was necessary (Boothroyd et al., 2001; Lager and Storm, 2013; Wheelwright and Clark, 1994). The capability to deploy appropriate integration mechanism is closely linked to the knowledge integration component of dynamic capabilities theory that postulate that firms need to be able to systematically pull together the knowledge developed internally, and combine it with the one from external sources in novel ways (Eriksson, 2014). We summarise the integration mechanisms and their use across the projects with different complementarity types in Table 5.

\begin{tabular}{|c|c|c|}
\hline Activities & $\begin{array}{c}\text { Extent of } \\
\text { complementarity } \\
\text { in the NPPD } \\
\text { project (from high } \\
\text { to low) }\end{array}$ & Examples from case studies \\
\hline $\begin{array}{l}\text { Choosing suitable } \\
\text { integration } \\
\text { mechanisms(s) to } \\
\text { manage the extent of } \\
\text { complementarity } \\
\text { between product and } \\
\text { process innovation }\end{array}$ & $\begin{array}{l}\text { Reciprocal } \\
\text { (draught beer in a } \\
\text { can) }\end{array}$ & $\begin{array}{l}\text { - Design for manufacturing was adopted to achieve the highest cost } \\
\text { efficiency of production and the product technology; the key } \\
\text { consideration in the success of the filling and canning process was to } \\
\text { maintain the existing canning speeds or improve them } \\
\text { - The three integrators were full-time general managers responsible for } \\
\text { leading the project; this included internal cross-functional } \\
\text { collaboration and each also acted as a gatekeeper in collaborations } \\
\text { with the external parties. The cross-functional expertise of the } \\
\text { integrators enabled them to effectively supervise all NPPD stages }\end{array}$ \\
\hline
\end{tabular}




\begin{tabular}{|l|l|l|}
\hline & $\begin{array}{l}\text { Product Sequential } \\
\text { (UHT milkshake) }\end{array}$ & $\begin{array}{l}\text { - The steps portrayed by the Stage Gate Model were followed with } \\
\text { monthly innovation reviews } \\
\text { - The R\&D team made up of scientists, product technology people and } \\
\text { packaging specialists handed the product concept over to the } \\
\text { processing/packaging specialists who ensured that the UK site } \\
\text { collaborated effectively with Spanish co-packer, devoting a significant } \\
\text { amount of time and resources to ensure a smooth start of production }\end{array}$ \\
\hline $\begin{array}{l}\text { Process } \\
\text { Amensalism } \\
\text { (mini-wafers) }\end{array}$ & $\begin{array}{l}\text { - Knowledge integration between bakery's mastery of the product and } \\
\text { existing production process and supplier's knowledge in the } \\
\text { production of 'bolt-on goodies' to enable production line stretch }\end{array}$ \\
\cline { 2 - 3 } & $\begin{array}{l}\text { Process Pooled } \\
\text { (canned minced } \\
\text { beef) }\end{array}$ & $\begin{array}{l}\text { - Factory manager and NPD manager supervised and encouraged the } \\
\text { execution of the project }\end{array}$ \\
\hline
\end{tabular}

Table 5. Deployment of suitable integration mechanisms - an overview of findings from the four case studies

The Process Amensalism project - the mini-wafers - was considered to be an incremental product innovation that was in response to a growing 'minification' trend in the food and drink industry. To portray the issue, the premium biscuit manufacturer's entire product portfolio was oriented towards producing incremental product innovations through minimal or no changes to the production equipment. As argued by the firm's commercial director:

\author{
"The existing machinery is a constraining factor. We always find that there are \\ certain areas that stop us from doing something. For example, we often have to make \\ compromises with the product design."
}

This was the case also in the mini-wafers project, and the project team was aware that it would have to work within the constraints of a production line used for the standard size wafers. Although the bakery had product development knowledge, it did not have sufficient internal capabilities to make changes to the production equipment. Furthermore, the equipment was sourced from United States, and it would have been difficult to cooperate with its supplier due to the distance and higher cost involved. Therefore, the production 
manager decided to conduct a brief market research. He found a small local engineering company, which after being provided with a briefing from the product development team came up with a solution by developing a new plastic container with a higher number of holes that were added to the tray used during production of regular sized wafers. The new tray was a bolt-on goodie (Aylen, 2013) that could be easily exchanged with the existing tray that was used for production of regular size wavers, without any additional changes to the production line.

On the contrary, the project of UHT milkshake that was characterised by Product Sequential complementarity, required a more complex cross-functional initiative. This required the involvement of Marketing, Sales, Operations and Technical departments during the different stages of project's development. Although each department adopted different management techniques to meet the project aims (e.g., procurement team adopted quality checklists), the project was managed using the Stage-Gate ${ }^{\circledR}$ Idea-to-Launch Model (Cooper, 2008). As stated by the marketing director:

"Stage-Gate Process was utilised with monthly catch-up meetings. Firstly, we checked the interest in the project with the board of directors ... then lab samples were done to check whether the project would be feasible ... only afterwards we considered development. At each stage, new people were involved in the project."

Initially, the dairy manufacturer considered a possibility to produce the UHT milkshake in their existing UK production facility, where the fresh version of the milkshake was being produced. The team quickly realised that, due to the unique nature of the UHT product, a completely sterile environment would be necessary. However, this would demand the development of a new production plant, requiring a significant investment. At this time, the procurement team identified an opportunity to outsource the production to a third-party co- 
packer which was already producing a UHT milk. The dairy team had to undertake several visits to set up the production at partner's premises. Furthermore, the project team needed to develop and integrate new processes to ensure the quality targets were met (quality checks and standards), and logistics concerning milk deliveries optimised. Despite this, an option to involve third party was much cheaper and considered by company as a better medium-term solution than the development of a new plant.

\subsection{Capability to leverage the developed/acquired knowledge and experience in the NPPD} project

The third dynamic capability is the ability to leverage the outputs and learnings from undertaken projects. Following successful execution of the project, the project teams need to codify and share the new knowledge within the broader organisation. Findings from the four case studies support prior literature and demonstrate that effective management of complementarity between product and process innovation enhances production equipment efficiency, quality of products, and also leads to application of newly developed knowledge in future projects (Kim et al., 1992; Martínez-Ros and Labeaga, 2009; Swink and Calantone, 2004). Additionally, we provide insights into further immediate, short-term and long-term benefits such as; simplification of manufacturing processes, provision of a stepping stone for development of technology platform, enhanced profitability of the company and creation of barriers to entry for the competition. For instance, after the Process Pooled complementarity project, bar pressure in the cookers was decreased almost across an entire product portfolio leading to more effective flow of work in the production. As the NPD manager said: 
"Since this project we have applied lower pressures across almost all products ... previously we tended to use different pressures for different products that has led to problems in the production, due to different shifts changing on a regular basis."

Additionally, our results uncovered that the complex and novel projects portraying the higher extent of complementarity are likely to provide, apart from immediate and short-term gains, significant long-term benefits to the company (Rivkin, 2000; Wheelwright and Clark, 1994). Successful complementarity management in the case of Reciprocal complementarity provided the brewery with a unique competitive advantage through patents and intellectual property rights that were for the competition difficult to imitate. Integrators supervising the project codified the novel discoveries and functioning of the technology to ensure that it did not remain with the external collaborators. In the following years, it continued to leverage the codified knowledge by working on cost reductions of the plastic insert production, processing costs for fitting the inserts into the container and more effective product technology. Furthermore, the brewery collaborated with a packaging developer and introduced a 0.53 litre can that made it possible to apply the product technology to milkshakes, mixed drinks, yoghurt-based drinks and coffee drinks. In essence, our findings resemble two of the focal elements of dynamic capabilities; ability to disseminate individually and organisationally held knowledge as well as organisational proactivity by leveraging the existing knowledge for new purposes (Eriksson, 2014). Table 6. provides an overview of findings from the four case studies.

Critical capability: Leveraging developed/acquired knowledge and experience 


\begin{tabular}{|c|c|c|}
\hline Activities & $\begin{array}{l}\text { Extent of } \\
\text { complementarity } \\
\text { in the NPPD } \\
\text { project (from high } \\
\text { to low) }\end{array}$ & Examples from case studies \\
\hline \multirow{4}{*}{$\begin{array}{l}\text { Leverage } \\
\text { immediate, short- } \\
\text { term and long- } \\
\text { term } \\
\text { opportunities }\end{array}$} & $\begin{array}{l}\text { Reciprocal } \\
\text { (draught beer in a } \\
\text { can) }\end{array}$ & $\begin{array}{l}\text { Immediate benefits: } \\
\text { - Introduction of a new to the market product } \\
\text { - Consumers' ability to take the pub experience to their homes } \\
\text { Short-term benefits: } \\
\text { - Further improvement and simplification of the existing product } \\
\text { technology and manufacturing process } \\
\text { Long-term benefits: } \\
\text { - Development of a unique competitive advantage } \\
\text { - Difficult to imitate product technology ensured by patenting the } \\
\text { technology } \\
\text { - Opened up opportunities for licensing of product technology } \\
\text { - Introduced the froth-forming technology to the bottled beer range }\end{array}$ \\
\hline & $\begin{array}{l}\text { Product } \\
\text { Sequential } \\
\text { (UHT milkshake) }\end{array}$ & $\begin{array}{l}\text { Immediate benefits: } \\
\text { - Introduction of a new to the company UHT milkshake } \\
\text { - Enhanced brand awareness in new distribution channels } \\
\text { - Increased shelf-life of the product led to less wastage } \\
\text { Short-term benefits: } \\
\text { - Introduction of a smaller } 330 \mathrm{ml} \text { 'grab and go size' milkshake } \\
\text { - Introduction of new flavours; i.e., Chocolate Fudge Brownie, } \\
\text { Strawberry } \\
\text { - Became one of the four key brands to drive the increased sales of } 15 \% \\
\text { the year after the introduction } \\
\text { Long-term benefits: } \\
\text { - The packaging innovation and UHT milkshake were starting points in } \\
\text { the development of a technology platform aimed at developing next- } \\
\text { generation packaging and temperature tolerance products } \\
\text { - Resulted in a 'turnaround' of lagging dairies division and development } \\
\text { of state-of-the-art production plant in the UK }\end{array}$ \\
\hline & $\begin{array}{l}\text { Process } \\
\text { Amensalism } \\
\text { (mini-wafers) }\end{array}$ & $\begin{array}{l}\text { Immediate benefits: } \\
\text { - Extended the product range to mini-wafers } \\
\text { Short-term benefits: } \\
\text { - Introduction of further flavours, i.e., Cheese and Thai-sweet } \\
\text { - The same tray was further utilised to produce macaroons } \\
\text { - Introduction of the mini-wafers opened opportunities to approach } \\
\text { further markets, i.e., on-the-go, airline and coffee shops }\end{array}$ \\
\hline & $\begin{array}{l}\text { Process Pooled } \\
\text { (canned minced } \\
\text { beef) }\end{array}$ & $\begin{array}{l}\text { Immediate benefits: } \\
\text { - Overall equipment efficiency increased by } 30 \% \\
\text { - The product quality was enhanced } \\
\text { Short-term benefits: } \\
\text { - The lower bar pressure during cooking was applied across most } \\
\text { canned products ( } 137 \text { products) }\end{array}$ \\
\hline
\end{tabular}

Table 6. Leveraging developed/acquired knowledge and experience - an overview of findings from the four case studies 


\subsection{Discussion: Research propositions and empirical framework}

The creative-intuitive aspect of abductive research and its ability to distinguish between general and particular features of a situation makes this approach suitable for formulation of propositions. Following the principles of systematic combining, we were able to determine which aspects of complementarity management are theoretically generalisable and which pertain to a specific situation and context (Kovácz and Spens, 2005). We present our findings in the form of five propositions that open avenues for future research. Lastly, we integrate these propositions into a practical framework that acts as a complementarity management tool for project managers in the food and drink industry and also informs the policy and educational curriculum development.

Our data demonstrate that the existing internal knowledge in product and process development was a critical building block in all projects that we studied. However, the more complex and novel the projects, the higher was the likelihood that project teams would need to identify suitable external collaboration parties that would contribute with the knowledge that was lacking internally. In such projects, firm's existing internal technical knowledge played a vital role in project team's ability to identify and incorporate other partner's knowledge, resembling the concept of absorptive capacity (Cohen and Levinthal, 1990; Zahra and George, 2002). Zahra and George (2002) argue that it is necessary that firms not only focus on acquisition and assimilation of the external knowledge (potential absorptive capacity) but also on its transformation and exploitation (realised absorptive capacity). This enables them to not only continuously renew their knowledge stock but, at the same time to incorporate transformed knowledge into their operations (Dahlander and Gann, 2010; Ritala and Hurmelina-Laukkanen, 2013). 
In our study we uncovered that the level of complexity and novelty was directly proportional to the extent of complementarity between product and process innovation. Our findings are in line with prior studies that postulate that the extent of required integration between different tasks in a particular project is determined by its complexity and degree of novelty to the firm (Bergfors and Lager, 2011; Lager and Frishammar, 2012; Van Echelt et al., 2008). For instance, complex projects involving a significant degree of risk require a higher integration, i.e., Reciprocal complementarity (Lawrence and Lorsch, 1967; Swink and Calantone, 2004; Vandevelde and Van Dierdonck, 2003). On the contrary, in a low extent of complementarity, i.e., Process Pooled complementarity, the project team work primarily with their existing expertise gained from years of experience in trying to enhance the efficiency of their production lines. The strategy of 'making the most of what we already have' is common particularly across the low technology process industries (i.e., line stretch and bolt-ons) (Aylen, 2013; Lager and Storm, 2013). Based on the foregoing discussion we advance the following propositions:

Proposition 1. Capability to identify complementarity in a NPPD project is dependent upon a correct assessment of how novel and complex the product and process developments are to the company.

Proposition 2. Capability to identify the complementarity in a NPPD project is dependent upon a correct assessment of the existing internal resources, and the ability to identify external resources and knowledge stocks for the project.

The studied cases also show that project managers have an array of integration mechanisms to choose from when dealing with a new project. However, due to the heterogeneous nature 
of these projects, after identifying a complementarity type, they need to deploy suitable integration mechanism(s). As demonstrated in our case studies, projects with a low extent of complementarity often rely on internal collaboration between the product development and production team or suppliers of production equipment. In contrast, projects with a high extent of complementarity require the application of several integration mechanisms to ensure smooth execution of the project. This finding is in line with existing research and suggests that different mechanisms should be combined to complement each other's strengths and weaknesses (Cua, McKone and Schroeder, 2001). However, these studies do not specify under what conditions, and how they should be combined. Achieving an ideal level of integration is crucial to avoid wasting valuable resources and time (Song and Thieme, 2006). Based on this discussion, we advance the following proposition:

Proposition 3. Capability to manage the complementarity in a NPPD project is dependent upon the ability to choose the most suitable integration mechanism(s) for the identified complementarity type.

Our results provide further evidence that an essential part of effective complementarity management is firm's ability to leverage opportunities from new learnings and experience achieved during the project (i.e., transferring knowledge from the project to the firm level). This finding is in line with research of Martínez-Ros and Labeaga (2009) and Wheelwright and Clark (1994) who found that companies can build upon the learnings from one project in the development of future innovations. However, food and drink companies often do not have formal processes to codify the 'lessons learned,' especially following the unsuccessful projects (Fortuin and Omta, 2009; Siguaw 2006). Our data shows that an ability to leverage the knowledge and experience gained through project's execution immediately (i.e., equipment efficiency improvement, introduction of a new product) and in the short-term (i.e., 
use of process improvement to produce new products, continuous enhancement of product and process technologies), is possible across all complementarity types. However, more significant long-term opportunities (i.e., development of the next-generation products based on novel product technology, difficulty to develop or integrate the new technology by competitors) are associated with a higher extent of complementarity. This finding points to the 'trap' that many companies may find themselves in when focusing mainly on incremental innovation in their project portfolio. Meanwhile, those who pursue more radical innovation can benefit from doing so in many years to come. Based on the preceding discussion, we propose:

Proposition 4. The capability to benefit from a low extent of complementarity in the NPPD project is dependent upon the ability to leverage developed/acquired knowledge and experience immediately or in the near future.

Proposition 5. The capability to benefit from a high extent of complementarity in the NPPD project is dependent upon the ability to leverage developed/acquired knowledge and experience immediately, near future as well as in the long-term.

We synthesised the five propositions into the framework (See Figure 2) that acts as a tool for NPPD project managers to effectively manage projects with different extents of complementarity between product and process innovation. In essence, the framework depicts three interdependent critical capabilities and associated activities. These are not per se novel to the innovation management literature, however, what is novel is how these capabilities are connected and how they reinforce one another. Arguably, focusing on the interaction between the capabilities rather than considering them in isolation, helps to establish a more holistic approach to managing projects with different extents of complementarity between product 
and process innovation. Therefore, our framework illustrates these capabilities in the form of three overlapping circles: a) identify the complementarity type, b) deploy suitable integration mechanism(s), and c) leverage developed/acquired knowledge and experience. We have integrated the propositions into corresponding capability 'circles.' Within our framework, these propositions can be viewed as means to establishing the desired capability. Furthermore, the bi-directional arrows that connect the capability 'circles' further reinforce the interdependent nature of the three dynamic capabilities. For instance, in the case when the project manager incorrectly identifies the complementarity type, it will impede project's execution (i.e., increased development time, shortage or underutilisation of already committed resources, over-skilled or under-skilled project team). In essence, this can lead to an uneven distribution of resources (e.g., human, material, time) within the company's project portfolio, resulting in increased cost and lost opportunities due to unnecessary trade-offs. Lastly, the arrow that links capability to leverage and identify, forms the vital feedback loop that facilitates firms' learning and integration of new practices and processes from both successful as well as unsuccessful projects. This study, therefore, provides a starting point in research on: How managers effectively allocate resources to NPPD project with different extents of complementarity between product and process? How is the choice of integration mechanisms influenced by the type of complementarity present in the project? How are the companies able to utilise the newly acquired knowledge in their future projects? 


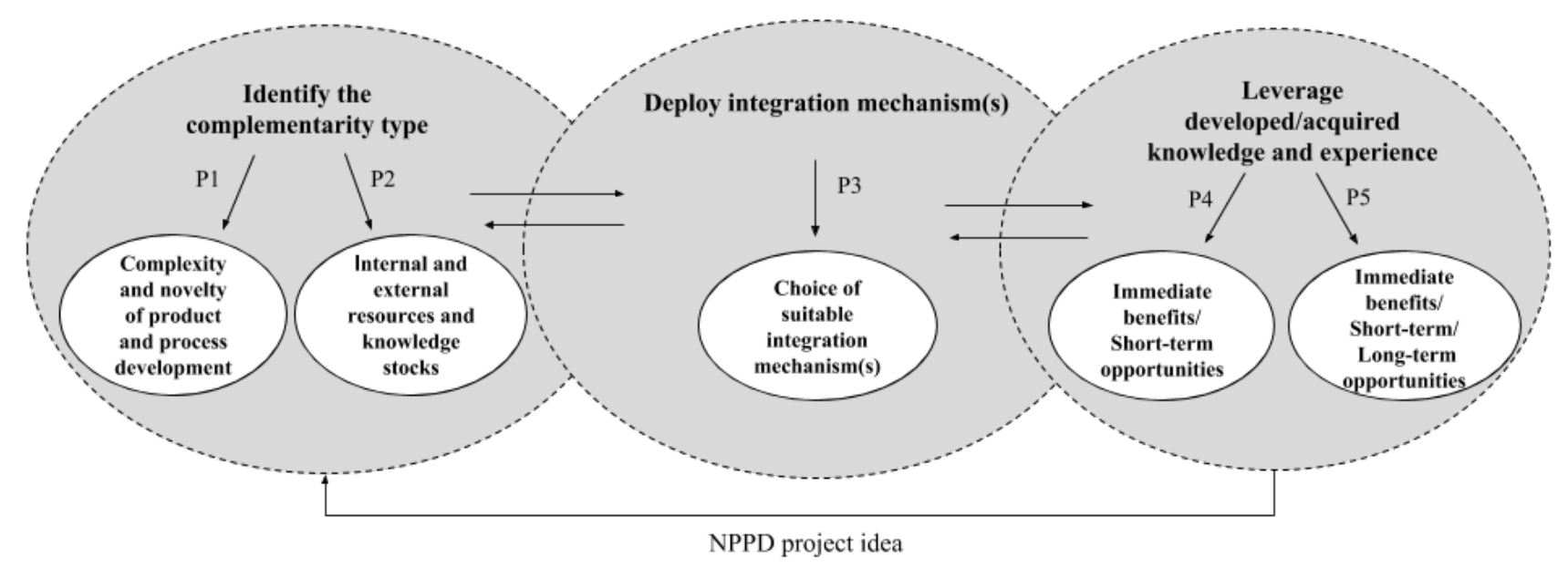

Figure 2. Framework to manage the complementarity between product and process innovation in NPPD projects

\section{Research limitations and future research}

Both, the core strength and the main weakness of our study rests on the fact that all four cases were chosen subjectively. While this allowed us to choose the most representative cases that provide rich empirical accounts of different types of complementarities present at various NPPD projects, we have also opened ourselves to the scrutiny of bias. However, we undertook this risk knowing that no in-depth insights into complementarity management at project level exists in the innovation literature despite its significance for practice and policy. We hope that along with Hullova et al. (2016), our work will inspire innovation scholars to continue the journey in search of complementarity management best practices. Hopefully, this will lead to the emergence of not only new complementarity management theory and new policies but also, an increased number of useful project management tools for practitioners in process industries. The other limitation of our study is the context in which we carried our data collection; the UK food and drink industry. While many differences between the low- 
technology process industries exist, the core characteristics of complementarity between product and process innovation in their NPPD projects are shared among all process industries. Therefore, we believe that our findings can be to a certain extent extended and inform practice and policy beyond the food and drink industry.

To build further upon our findings, we recommend future research to conduct empirical studies in high, medium and low technology process industries to test our propositions. To overcome the main limitation of our study, researchers could focus on comparing several case studies of the same complementarity type and make cross-case comparisons using our empirical framework as a starting point for design of their study, and initial analysis. In addition, we recommend future research to provide practical guidance on integration mechanisms that can aid the work of project teams when being faced with different complementarity types in NPPD projects. Lastly, we suggest that the future versions of the CIS survey should incorporate a section on management of complementarities between product and process innovation. Doing so will allow us to gain valuable insights into complementarity management in NPPD projects across a broad range of industries in the EU. At present, the survey includes three separate sections on product innovation, process innovation, and organisational innovation. The organisational innovation is addressed in only three 'yes or no' questions that were added in 2010 (European Commission, 2018). We believe that including a more detailed section on complementarity identification and management within the respondents' NPPD projects will prove fruitful for extending our knowledge, developing management tools, shaping the policy and sharing the best practice across the EU firms. Our empirical framework can inform the set of questions that can be integrated into the future version of the CIS survey. By integrating questions related to how companies identify and manage different complementarity, and how these differ in various 
projects, we can examine their awareness and the level of understanding of complementarities. For instance, it would be interesting to have a question asking the respondents to indicate what are the most commonly used integration mechanisms in their NPPD projects and whether they find them beneficial (e.g., the speed of execution, quality of the product). To do so, respondents could be provided with a list of different mechanisms, including their descriptions and possible applications, from which they could choose the ones they use in different projects (i.e., integration mechanisms used in Table 1 can be used as a starting point). Furthermore, another question can be introduced to gain insights into the impact that choice of these mechanisms had on companies' project execution (i.e., this can be centered around an overview of different benefits summarised in Table 2. and our findings).

\section{Conclusion}

This paper makes two main contributions: to have developed empirically derived framework to manage complementarity between product and process innovation; and to have provided comprehensive empirical insights into complementarity management in four NPPD projects illustrating a range of complementarity types, conceptualised by Hullova et al. (2016). Building on the perspectives from contingency theory and dynamic capabilities, we provide evidence that NPPD projects differ in their complementarity management strategies. Further, we have uncovered the shared commonalities that were present at each NPPD project irrespective of the complementarity present. These commonalities revolve around the need to master three critical capabilities: capability to identify the complementarity type, capability to deploy suitable integration mechanisms, and capability to leverage learnings from the project immediately, in short and long-term. 
The capability to identify the complementarity type is particularly important because the success of an entire project depends on manager's ability to identify correct complementarity type present in the project that the firm is considering to undertake. For instance, in NPPD projects with a low extent of complementarity project team builds upon existing tacit knowledge and experience. However, projects with a high extent of complementarity require collaboration with external parties to develop novel product technologies and to make significant adjustments to the existing production equipment. Therefore, an inappropriate resource allocation, overestimation of internal capabilities or inability to identify suitable external knowledge sources could lead to a significant increase in time and financial resources. Equally, the ability to deploy a suitable integration mechanism(s) is vital during the execution of the project. Our findings suggest that projects with high extent of complementarity (i.e., Reciprocal complementarity) require combination of several integration mechanisms to facilitate the synchronous adoption of product and process innovation (e.g., design for manufacturing and assembly; cross-functional collaboration; integrators to supervise internal and external knowledge development). On the contrary, projects with a low extent of complementarity (i.e., Process Amensalism) could suffice with a single integration mechanism such as 'knowledge integration with equipment suppliers' to produce a quick and cost-effective solution. Our findings contrast with prior studies, which tended to assume that the commonly cited techniques such as 'QFD' and 'concurrent engineering' are applicable in all types of projects, irrespective of the industry context and complementarity types (Chen, 2009; Droge, Jayaram and Vickery, 2004). The last critical capability is the ability to leverage knowledge learned and resources acquired in the NPPD project. This can be achieved immediately, as evidenced by the prior research (Kim et al., 1992; Nobelius, 2004; Swink, 2006). However, these benefits can also extend to the short and long-term. The evidence from the four case studies shows that even projects with a low extent 
of complementarity can provide firms not only with immediate, but also several short-term benefits. This capability is mainly dependent upon firm's ability to codify, retain and exploit newly acquired knowledge from broad range of the projects.

In addition, we provide detailed and unified insights into activities related to effective management of different complementarity types at the NPPD project level. Prior research was predominantly based on conceptual contributions and large-scale surveys at the industry or company level (Battisti and Stoneman, 2010; Evangelista and Vezzani, 2010). Our findings, in particular contribute to the limited number of empirical studies on complementarity management in the low technology process industries (Lager and Storm, 2013; Lager, Blanco and Frishammar, 2013).

\section{Managerial and policy implications}

Our paper responses to one of the five main calls for policy change in the Food and Drink Federation Manifesto 2017; 'to help create a highly skilled home-grown talent that drives innovation.' FDF urges the next UK Government to work with them to ensure that the food and drink industry thrives in the years to come (FDF, 2017). We believe that in-depth insights into the effective complementarity management in NPPD projects may not only serve as educational material for specialised degrees in Food Engineering but, they could also inform the industry by providing tools and examples of the best practice from which the aspiring managers can learn from. The key implications of our study can be integrated into the existing project management tools to allow companies to fully benefit from each NPPD project undertaken (i.e., decreased time to market, improved utilisation of resources, increased accumulation codification of knowledge). This is of particular importance because product and process development managers in the food and drink industry are facing a 
challenging task to manage a broad portfolio of NPPD projects. Each of these projects is characterised by a different type of complementarity, and it is critical for managers to be able to correctly identify the type of complementarity between product and process in the potential NPPD, then choose an appropriate integration mechanism and finally leverage the outputs and learnings from the project.

Based on our framework, the identification of complementarity requires managers to assess the complexity and novelty of the planned product and process developments to the organisation along with an assessment of availability of the existing internal resources and knowledge. In instances, when the company does not possess needed resources or knowledge, managers need to be able to identify suitable external collaborators. Such step enables the project team to adopt appropriate integration mechanisms to manage the identified complementarity type. To do so, the project management team is required to be aware of a broad range of integration mechanisms and their application. Every project, whether successful or not has a potential to provide valuable learnings for the company. Therefore, the third part of our framework highlights the importance of leveraging the outputs, experience and learnings from undertaken projects. However, many companies underestimate the importance of such learnings, often fail to codify, and share it with a broader organisation. Consequently, this leads to significant knowledge losses and missed opportunities because such knowledge can only be acquired through experience and is often difficult to absorb from external sources. The three dynamic capabilities illustrated in our framework are sequential and interdependent; therefore, it will not be sufficient to develop only one of the capabilities to manage the complementarity effectively. We believe that our framework is particularly suitable for food and drink companies that predominantly undertake a large number of incremental product and process innovations as opposed to 
having an ambidextrous project portfolio. Many companies within this industry lack experience in managing projects with a high extent of complementarity. The framework will help them to think systematically about their NPPD projects and develop capabilities need for successful management of complementarities in their complex project portfolios.

\section{Acknowledgements}

We would like to thank the anonymous reviewers for their provision of extensive comments that helped us to significantly enhance the quality of our paper. We are also indebted to Professor David Pickernell for proofreading the paper and providing us with a number of ideas that helped us to enhance its quality. 
Appendix 1.

\begin{tabular}{|c|c|c|c|}
\hline $\begin{array}{l}\text { NPPD project/ case } \\
\text { study }\end{array}$ & Job position/role & $\begin{array}{l}\text { No. of } \\
\text { interviews }\end{array}$ & $\begin{array}{l}\text { Duration of } \\
\text { interviews } \\
\text { (minutes) }\end{array}$ \\
\hline Draught beer & $\begin{array}{l}\text { General manager of the project } \\
\text { Ex-managing director at the brewery } \\
\text { Ex-managing director at } \\
\text { gas supplying company } \\
\text { Brewing specialist } \\
\text { Packaging expert } \\
\text { NPD manager at plastics specialist company }\end{array}$ & $\begin{array}{l}2 \\
2 \\
1 \\
1 \\
1 \\
1 \\
1\end{array}$ & $\begin{array}{l}60,30 \\
56,50 \\
48 \\
60 \\
50 \\
42\end{array}$ \\
\hline UHT milkshake & $\begin{array}{l}\text { Marketing director responsible for 5-year } \\
\text { turnaround of Diaries Business Unit } \\
\text { Marketing manager at Diaries Business Unit } \\
\text { Sales director at processing and filling lines } \\
\text { supplier } \\
\text { Operations manager at packaging supplier }\end{array}$ & $\begin{array}{l}1 \\
1 \\
2 \\
1\end{array}$ & $\begin{array}{l}45 \\
45 \\
115,120 \\
55\end{array}$ \\
\hline Jalapeno mini-wafers & $\begin{array}{l}\text { Commercial director } \\
\text { Owner of premium snacks manufacturing } \\
\text { company } \\
\text { Production manager }\end{array}$ & $\begin{array}{l}2 \\
1 \\
1\end{array}$ & $\begin{array}{l}90,20 \\
45 \\
60\end{array}$ \\
\hline Canned minced beef & $\begin{array}{l}\text { NPD manager } \\
\text { Operations manager } \\
\text { Technical manager }\end{array}$ & $\begin{array}{l}4 \\
1 \\
1\end{array}$ & $\begin{array}{l}90,85,90,95 \\
58 \\
45\end{array}$ \\
\hline
\end{tabular}

An overview of the interviews conducted for the four illustrative case studies 


\section{References}

Abernathy, W. J., \& Utterback, J. M. (1978). Patterns of industrial innovation. Technology Review. June-July, 41-47.

Adegbesan, J. A. (2009). On the origins of competitive advantage: Strategic factor markets and heterogeneous resource complementarity. Academy of Management Review, 34(3), 463475 .

Adler, P. S. (1995). Interdepartmental interdependence and coordination: The case of the design/manufacturing interface. Organization Science, 6(2), 147-167.

Akao, Y. (1990). Quality Function Deployment Integrating Customer Requirement into Product Design, Portland, OR: Productivity Press.

Akao, Y., \& Mazur, G. H. (2003). The leading edge in QFD: Past, present and future. International Journal of Quality \& Reliability Management, 20, 20-35.

Aylen, J. (2013). Stretch: How innovation continues once investment is made. $R \& D$ Management, 43, 271-287.

Baker, Ch. G. J. (2013). Handbook of Food Factory Design. New York: Springer.

Ballot, G., Fakhfakh, F., Galia, F., \& Salter, A. (2015). The fateful triangle:

Complementarities in performance between product, process and organizational innovation in France and the UK. Research Policy, 44, 217-232.

Barras, R. (1986). Towards a theory of innovation in services. Research Policy, 15, 161-173. Battisti, G., \& Stoneman, P. (2010). How Innovative are UK Firms? Evidence from the Fourth UK Community Innovation Survey on synergies between technological and organizational innovations. British Journal of Management, 21, 187-206.

Bellgran, M. (1998). Systematic Design for Assembly Systems: Preconditions and Design Process Planning. Linköping Studies in Science and Technology, Dissertation No. 515. Linköping University, Linköping.

Bellgran, M. \& Säfsten, K. (2010). Production Development: Design and Operation of Production Systems. London: Springer-Verlag.

Bergfors, M., \& Lager, T. (2011). Innovation of process technology: Exploring determinants for organizational design. International Journal of Innovation Management, 15, 1113-1140.

Bigliardi, B., \& Galati, F. (2013). Innovation trends in the food industry: The case of functional foods. Trends in Food Science and Technology, 31, 118-129.

Blumer, H. (1954). What is wrong with social theory?. American sociological review, 19(1), 3-10.

Boothroyd, G., Dewhurst, P., \& Knight, W. A. (2001). Product design for manufacture and assembly (2nd edition). Retrieved from https://ebookcentral.proquest.com

Bowen, G. A. (2006). Grounded theory and sensitizing concepts. International journal of qualitative methods, 5(3), 12-23. 
Bruch, J. \& Bellgran, M. (2014). Integrated portfolio of products and production systems. Journal of Manufacturing Technology Management, 25(2), 155-174.

Capitanio, F., Coppola, A. \& Pascussi, S. (2010). Product and process innovation in the Italian food industry. Agribusiness, 26(4), 503-518.

Cassiman, B., \& Veugelers, R. (2006). In search of complementarity in innovation strategy: Internal R\&D and external knowledge acquisition. Management Science, 52, 68-82.

Chen, C. C. (2009). Integration of quality function deployment and process management in the semiconductor industry. International Journal of Production Research, 47(6), 1469-1484.

Cohen, W. M., \& Levinthal, D. A. (1990). The implications of spillovers for R\&D investment and welfare: a new perspective. Administrative Science Quarterly, 35(1990), 128-152.

Cooper, R. G. (2008). Perspective: The Stage-Gate Idea-to-Launch Process-Update, what's new, and NexGen Systems. Journal of Product Innovation Management, 25, 213-232.

Cua, K. O., McKone, K. E., \& Schroeder, R. G. (2001). Relationships between implementation of TQM, JIT, and TPM and manufacturing performance. Journal of Operations Management, 19(6), 675-694.

Dahlander, L., \& Gann, D. M. (2010). How open is innovation?. Research Policy, 39(6), 699709.

Damanpour, F. (2010). An integration of research findings of effects of firm size and market competition on product and process innovations. British Journal of Management, 21, 9961010 .

Damanpour, F. (2014). Footnotes to research on management innovation. Organization Studies, 35(9), 1265-1285.

Damanpour, F., \& Gopalakrishnan, S. (2001). The dynamics of the adoption of product and process innovation in organizations. Journal of Management Studies, 38, 45-65.

Donaldson, L. (2001). The Contingency Theory of Organizations. Thousand Oaks, California: Sage Publications Inc.

Droge, C., Jayaram, J., \& Vickery, S. K. (2004). The effects of internal versus external integration practices on time-based performance and overall firm performance. Journal of Operations Management, 22(6), 557-573.

Dubois, A. \& Gadde, L. E. (2002). Systematic combining: an abductive approach to case research. Journal of Business Research, 55, 553-560.

Dubois, A., \& Araujo, L. (2007). Case research in purchasing and supply management: Opportunities and challenges. Journal of Purchasing and Supply Management, 13(3), 170181.

Dubois, A., \& Gadde, L. E. (2014). Systematic combining- A decade later. Journal of Business Research, 67(6), 1277-1284. 
Dubois, A., \& Gibbert, M. (2010). From complexity to transparency: managing the interplay between theory, method and empirical phenomena in IMM case studies. Industrial Marketing Management, 39, 129-136.

Edmondson, A. C. \& McManus, S. E. (2007). Methodological fit in management field research. Academy of Management Review, 32(4). 1155-1179.

Eisenhardt, K. M., \& Martin, J. A. (2000). Dynamic capabilities: What are they? Strategic Management Journal, 21(10-11), 1105-1121.

Ennen, E., \& Richter, A. (2010). The whole is more than the sum of its parts - or is it? A review of the empirical literature on complementarities in organizations. Journal of Management, 36, 207-233.

Eppinger, S. D. (1991). Model-based approaches to managing concurrent engineering. Journal of Engineering Design, 2(4), 283-290.

Eriksson, T. (2014). Processes, antecedents and outcomes of dynamic capabilities. Scandinavian Journal of Management, 30(1), 65-82.

Ettlie, J. E. (1995). Product-process development integration in manufacturing. Management Science, 41(7), 1224-1237.

European Commission (2018). Technology and Innovation Statistics. CIS2014_Harmonised Survey Questionnaire. Retrieved from:

https:/circabc.europa.eu/faces/jsp/extension/wai/navigation/container.jsp

Evangelista, R., \& Vezzani, A. (2010). The economic impact of technological and organizational innovations. A firm-level analysis. Research Policy, 39, 1253-1263.

Flyvberg, B. (2006). Five misunderstandings about case study research. Qualitative Inquiry, 12(2), 219-245.

Food and Drink Federation (FDF). (2017). FDF Manifesto 2017. Retrieved from: https://www.fdf.org.uk/corporate_pubs/FDF\%20Manifesto\%202017.pdf

Food and Drink Federation (FDF). 2018. Delivering Sustainable Growth through Innovation. Retrieved from: https://www.fdf.org.uk/growth-through-innovation.aspx

Fortuin, F. T., \& Omta, S. W. F. (2009). Innovation drivers and barriers in food processing. British Food Journal, 111(8), 839-851.

Frishammar, J., Lichtenthaler, U., \& Kurkkio, M. (2012). The front end in non-assembled product development: a multiple case study of mineral and metal firms. Journal of Engineering and Technology Management, 29(4), 468-488.

Guisado-González, M., Wright, L. T., \& Guisado-Tato, M. (2017). Product-process matrix and complementarity approach. The Journal of Technology Transfer, 42(3), 441-459.

Halkier, B. (2011). Methodological practicalities in analytical generalization. Qualitative Inquiry, 17(9), 787-797.

Hirsch-Kreinsen, H. (2008). "Low-tech" innovations. Industry \& Innovation, 15, 19-44. 
Hirsch-Kreinsen, H. (2015). Innovation in low-tech industries: Current conditions and future prospects. In O. Som and E. Kirner (2015) (Eds), Low-tech Innovation: Competitiveness of the German Manufacturing Sector (pp. 17-32). Switzerland: Springer International Publishing.

Hullova, D. (2017). Uncovering the complementarity between product and process innovation in New Product and Process Development Projects: An investigation in the UK food and drink sector. PhD thesis: University of Portsmouth, 1-301.

Hullova, D., Trott, P. \& Simms, C. D. (2016). Uncovering the reciprocal complementarity between product and process innovation. Research Policy, 45(5), 929-940.

Kim, J. S., Ritzman, L. P., Benton, W. C., \& Snyder, D. L. (1992). Linking product planning and process design decisions. Decision Sciences, 23, 44-60.

Kotabe, M., \& Murray, J. Y. (1990). Linking product and process innovations and modes of international sourcing in global competition: A case of foreign multinational firms. Journal of International Business Studies, 21, 383-408.

Kovács, G., \& Spens, K. M. (2005). Abductive reasoning in logistics research. International Journal of Physical Distribution \& Logistics Management, 35(2), 132-144.

Kurkkio, M. Frishammar, J., \& Lichtenthaler, U. (2011). Where process development begins: A multiple case study of front end activities in process firms. Technovation, 31, 490-504.

Lager, T. (2005). Multiple progression - a proposed new system for the application of quality function deployment in process industry. International Journal of Innovation Management, 9, 311-341.

Lager, T. (2011). Managing Process Innovation: From Idea Generation to Implementation. London: Imperial College Press.

Lager, T. (2016). Managing innovation \& technology in the process industries: Current practices and future perspectives. Procedia Engineering, 138, 459-471.

Lager, T. (2017). A conceptual analysis of conditions for innovation in the process industries and a guiding framework for industry collaboration and further research. International Journal of Technological Learning, Innovation and Development, 9(3), 189-219.

Lager, T. \& Rennard, J. P. (2014). Managing the manufacturing - R\&D interface: an extended editorial viewpoint. Journal of Manufacturing Technology Management, 25(2), 146-154.

Lager, T., \& Frishammar, J. (2012). Collaborative development of new process technology/equipment in the process industries: in search of enhanced innovation performance. Journal of Business Chemistry, 9, 67-84.

Lager, T., \& Storm, P. (2013). Application development in process firms: Adding value to customer products and production systems. $R \& D$ Management, 43(3), 288-302.

Lager, T., Blanco, S. \& Frishammar, J. (2013). Managing R\&D and innovation in the process industries. $R \& D$ Management, 43(3), 189-195. 
Lawrence, P. R., \& Lorsch, J. W. (1967). Organizations and Environment: Managing Differentiation and Integration. Boston, MA: Harvard Business School Press.

Lim, L. P. L., Garnsey, E. \& Gregory, M. (2006). Product and process innovation in biopharmaceuticals: a new perspective on development. $R \& D$ Management, 36(1), 27-36.

Martínez-Ros, E., \& Labeaga, J. M. (2009). Product and process innovation: Persistence and complementarities. European Management Review, 6(1), 64-75.

Milgrom, P., \& Roberts, J. (1995). Complementarities and fit: strategy, structure and organizational change in manufacturing. Journal of Accounting and Economics, 19, 179-208.

Nag, R., Hambrick, D. C., \& Chen, M. J. (2007). What is strategic management, really? Inductive derivation of a consensus definition of the field. Strategic Management Journal, 28(9), 935-955.

Nategh, M. J. (2009). Concurrent engineering planning on the basis of forward and backward effects of manufacturing processes. International Journal of Production Research, 47(18), $5147-5161$.

Nobelius, D. (2004). Towards the sixth generation of R\&D management. International Journal of Project Management, 22(5), 369-375.

Patton, M. Q. (1990). Qualitative Evaluation and Research Methods. Thousand Oaks, CA: SAGE Publications, Inc.

Pisano, G. P. (1997). The Development Factory: Unlocking the Potential of Process Innovation. Boston, MA: Harvard Business Press.

Pisano, G. P., \& Wheelwright, S. C. (1995). The new logic of high-tech R \& D. Long Range Planning, 28(6), 128-128.

Quintens, L., \& Matthyssens, P. (2010). Involving the process dimensions of time in casebased research. Industrial Marketing Management, 39, 91-99.

Ragatz, G. L., Handfield, R. B., \& Petersen, K. J. (2002). Benefits associated with supplier integration into new product development under conditions of technology uncertainty. Journal of Business Research, 55(5), 389-400.

Reichstein, T., \& Salter, A. (2006). Investigating the sources of process innovation among UK manufacturing. Industrial and Corporate Change, 15, 653-682.

Ritala, P., \& Hurmelinna-Laukkanen, P. (2013). Incremental and radical innovation in coopetition-The role of absorptive capacity and appropriability. Journal of Product Innovation Management, 30(1), 154-169.

Rivkin, J. W. (2000). Imitation of complex strategies. Management Science, 46(6), 824-844.

Robertson, P., Smith, K. \& von Tunzelmann, N. (2009). Innovation in low-and medium technology industries. Research Policy, 38, 441-446. 
Rosell, D. T., Lakemond, N. \& Wasti, S. N. (2014). Integrating knowledge with suppliers at the R\&D-manufacturing interface. Journal of Manufacturing Technology Management, 25(2), 240-257.

Ryynänen, T., \& Hakatie, A. (2014). We must have the wrong consumers-a case study on new food product development failure. British Food Journal, 116(4), 707-722.

Säfsten, K., Johansson, G., Lakemond, N. \& Magnusson, T. (2014). Interface challenges and managerial issues in the industrial innovation process, Journal of Manufacturing Technology Management, 25(2), 218-239.

Sekaran, U., \& Bougie, R. (2016). Research Methods for Business: A Skill Building Approach. New York, NY: John Wiley \& Sons.

Siguaw, J.A., Simpson, P.M. and Enz, C.A. (2006). Conceptualizing innovation orientation: a framework for study and integration of innovation research. The Journal of Product Innovation Management, Vol. 23, pp. 536-74.

Som, O. (2012). Innovation Patterns of Non-R\&D-Performing Firms in the German Manufacturing Industry. Germany: Gabler.

Søndergaard, D. M. (2002). Poststructuralist approaches to empirical analysis. International Journal of Qualitative Studies in Education, 15(2), 187-204.

Song, M., \& Thieme, R. J. (2006). A cross-national investigation of the R\&D-marketing interface in the product innovation process. Industrial Marketing Management, 35(3), 308322.

Swink, M. (2006). Building collaborative innovation capability. Research-Technology Management, 49(2), 37-47.

Swink, M. \& Calantone, R. (2004). Design-manufacturing integration as a mediator of antecedents to new product design quality. IEEE Transactions on Engineering Management. $51(4), 472-482$.

Thomä, J. (2017). DUI mode learning and barriers to innovation-a case from Germany. Research Policy, 46(7), 1327-1339.

Traill, W. B. \& M. Meulenberg, M. (2002). Innovation in the food industry. Agribusiness, 18, 1-21.

Trott, P., \& Simms, C. (2017). An examination of product innovation in low-and mediumtechnology industries: Cases from the UK packaged food sector. Research Policy, 46(3), 605-623.

Turkulainen, V., \& Ketokivi, M. (2012). Cross-functional integration and performance: What are the real benefits?. International Journal of Operations \& Production Management, 32(4), $447-467$.

Van Donk, D. P., \& Fransoo, J. C. (2006). Operations management research in process industries. Journal of Operations Management, 3(24), 211-214. 
Van Echtelt, F. E., Wynstra, F., Van Weele, A. J., \& Duysters, G. (2008). Managing supplier involvement in new product development: a multiple-case study. Journal of Product Innovation Management, 25(2), 180-201.

Vandevelde, A. \& Van Dierdonck, R. (2003). Managing the design-manufacturing interface. International Journal of Operations \& Production Management, 23(11), 1326-1348.

Weiss, P. (2003). Adoption of product and process innovation in differentiated markets: The impact of competition. Review of Industrial Organization, 23, 301-314.

Wheelwright, S. C., \& Clark, K. B. (1994). Accelerating the design-build-test cycle for effective product development. International Marketing Review, 11, 32-46.

Yin, R. K. (2009). Case Study Research: Design and Methods, $4^{\text {th }}$ ed. Thousand Oaks, CA: Sage Publications.

Zahra, S. A., \& George, G. (2002). Absorptive capacity: A review, reconceptualization, and extension. Academy of Management Review, 27(2), 185-203. 